\title{
Produced Water from Oil and Gas Exploration-Problems, Solutions and Opportunities
}

\author{
Feras Salem ${ }^{1}$, Thies Thiemann ${ }^{2 *}$ \\ ${ }^{1}$ Department of Biology, College of Science, United Arab Emirates University, Al Ain, Abu Dhabi, United Arab Emirates \\ ${ }^{2}$ Department of Chemistry, College of Science, United Arab Emirates University, Al Ain, Abu Dhabi, United Arab Emirates \\ Email: 201690415@uaeu.ac.ae, ^thies@uaeu.ac.ae
}

How to cite this paper: Salem, F. and Thiemann, T. (2022) Produced Water from Oil and Gas Exploration-Problems, Solutions and Opportunities. Journal of Water Resource and Protection, 14, 142-185. https://doi.org/10.4236/jwarp.2022.142009

Received: January 5, 2022

Accepted: February 22, 2022

Published: February 25, 2022

Copyright () 2022 by author(s) and Scientific Research Publishing Inc. This work is licensed under the Creative Commons Attribution International License (CC BY 4.0).

http://creativecommons.org/licenses/by/4.0/

\begin{abstract}
Large volumes of water are generated in gas- and oil-production. This includes the water that is present originally in the reservoirs, but also water that is injected into the wells. While currently much of the produced water is either reinjected or disposed of after treatment, treated produced water is increasingly seen as an interesting resource, especially in water-scarce regions. This review looks at different PW treatment methods available, with an emphasis on the management of PW in oil- and gas production on the Arabian Peninsula.
\end{abstract}

\section{Keywords}

Produced Water, Oil Exploration, Gas Exploration, Water Treatment

Methodology, Membrane Separation, Arabian Peninsula

\section{Introduction}

Produced water (PW) is a large waste stream that develops in onshore oil and gas exploration and production, where water is brought up from the reservoir together with the oil/gas. This water is a mixture of formation water, injection water, and small volumes of condensed water from gas production and aqueous residues of treatment chemicals. PW also makes for the largest waste stream by volume in oil and gas production operations on most offshore platforms [1] [2]. Produced water may account for $80 \%$ of the wastes and residuals produced from natural gas production operations [3]. Currently, the output of PW exceeds oil production at a volumetric ratio of estimated 2.4 globally, which interestingly is a little less than reported in 2009 with a ratio of 3:1 at the time [4] and 10:1 in 
the US [4], with a total oil production worldwide of 95.2 million barrels (2019). According to a 2020 report, PW production has reached 250 million barrels per day [5], $40 \%$ of which is discharged untreated into the environment [6]. With the maturation of oil fields, it is expected that the ratio produced water/extracted oil will increase further [7] [8]. As oil and gas production volumes reflect the overall economic market, economic downturns also lead to a decrease in PW from oil and gas production. The era of COVID-19 is such a case in point. Thus, in 2020 the amount of PW from on-shore oil production in the United States suffered a decline of $4 \%$, in comparison to 2019 , to a little over 20 million barrels, according to an IHS Markit analysis (IHS-Market analysis, 2020). Frack water will decrease the most, by about $46 \%$ vs. 2019 numbers. This leaves a US oilfield water market valued at 28 billion dollars [9]. In addition, one of the world's largest oil reserves, containing over 169 billion remaining barrels $(27 \times$ $10^{9} \mathrm{~m}^{3}$ ) of recoverable bitumen, is located in the surface mined Athabasca oil sands deposit northern Alberta, Canada [10]. Here, the extraction process results in raw tailings at a 9:1 volume ratio to extracted oil [11]. Thus, the future of oil sand exploration will also in part determine the amount and the nature of produced water in the future. Overall, the global produced water market is predicted at 87.4 billion dollars by 2031 [12].

With this large amount of PW produced, it is of immense importance to manage it, taking into account cost effectiveness and environmental sustainability. In 2020, M. Gray published the results of a survey of 14 member companies of IPIECA, the global oil and gas industry association for advancing environmental and social performance, on which factors govern decisions regarding the reuse of PW from their operations. The main factors that were identified were economic, regulatory (permits, social and corporate policy) and infrastructure [13]. In general, from an environmental standpoint, the principle of first employing technologies to minimize produced water production and of reusing and recycling PW govern. If neither of these is practical, PW disposal is the final option [14] [15]. Management of PW involves an injection into deep disposal wells; however, this technique may lead to induced seismicity, surface water and/or subsurface fresh water aquifer contamination. Nevertheless, it is less costly, therefore it is the most practiced strategy to date [16], with about $90 \%$ of produced water being reinjected into the subsurface for disposal or for enhanced oil recovery [17].

Also in the Middle East, sustainable management of PW has been of great interest for the past few decades. In the Arabian Peninsula, where three of the Middle East's major oil producing states are, concerns have been raised about the impact of the currently implemented techniques for PW disposal. There are four common PW disposal methods in the oilfields located in the Arabian Peninsula: seepage pits, sealed pits, effluent injection and recovery injection. Since the discovery of oil in the region, the producers have focused primarily on maintaining their high profitability by reducing their operational costs and un- 
necessary capital expenditure to the minimum. PW disposal was one of these cost reduction plans, sometimes disregarding their environmental risks, which were not given proper attention to on a global scale, either [18]. On the other hand, the Arabian Peninsula is one of the areas in the world with the highest water scarcity, with few permanent lakes and rivers, and reuse of PW in the region would be quite beneficial.

A number of reviews have been published to date on the treatment of produced water (PW) from oil and gas activities [7] [19]-[24]. Also, in 2018, T.C.M. Nonato et al. published a review of technologies treating PW, concentrating on their economic viability [25]. This review will concentrate on the management and the development of treatment methods of PW with an emphasis on the situation in the Arabian Peninsula.

\section{Characteristics of Produced Water}

Some of the typical PW constituents are salts (expressed as salinity, total dissolved solids (TDS), or electrical conductivity) (Table 1), oil and grease, BTEX (benzene, toluene, ethylbenzene, and xylenes), PAHs (polycyclic aromatic hydrocarbons), organic acids, and phenols. In addition, chemical additives can be found that come from the drilling, fracturing, or from operating the well. Some of them may have toxic properties [26]. These include biocides, demulsifiers, and scale and corrosion inhibitors from oil fields [22] [27] and methanol and diethylene glycol from gas fields [23].

Table 1. Typical elemental content of PW (in mg/L). ND = not detectable; $\mathrm{N} / \mathrm{A}=$ not available.

\begin{tabular}{|c|c|c|}
\hline Element/complex anion & Concentration (ppm) & References \\
\hline Antimony & N/A & \\
\hline Aluminum & $0.50-410$ & $\begin{array}{l}\text { USEPA, } 2000 \text { [29]; Tibbetts et al., } 1992 \text { [30]; Cluff et al., } 2014 \text { [31]; Warner et } \\
\text { al., } 2014 \text { [32]; Gregory et al., } 2011 \text { [33]; Yeung et al., 2011 [34]; Utvik et al., } \\
1999 \text { [35], Alley et al., } 2011 \text { [36]; Khan et al., } 2016 \text { [37] }\end{array}$ \\
\hline Arsenic & $0.004-151$ & $\begin{array}{l}\text { Fillo \& Evans, } 1990 \text { [38]; USEPA, } 2000 \text { [29]; Tibbetts et al., } 1992 \text { [30]; Ekins et } \\
\text { al., } 2006 \text { [39]; Cluff et al., } 2014 \text { [31]; Warner et al., } 2014 \text { [32]; Gregory et al., } \\
2011 \text { [33] }\end{array}$ \\
\hline Barium & ND - 1740 & $\begin{array}{l}\text { Fillo \& Evans, } 1990 \text { [38]; USEPA, } 2000 \text { [29]; Tibbetts et al., } 1992 \text { [30]; Cluff et } \\
\text { al., } 2014 \text { [31]; Warner et al., } 2014 \text { [32]; Gregory et al., } 2011 \text { [33]; Yeung et al., } \\
2011 \text { [34]; Utvik et al., } 1999 \text { [35], Alley et al., } 2011 \text { [36]; Khan et al., } 2016 \text { [37] }\end{array}$ \\
\hline Beryllium & $<0.001-0.004$ & Tibbetts et al., 1992 [30] \\
\hline Bicarbonate & ND - 14,750 & $\begin{array}{l}\text { USGS } 2002 \text { [40]; Nasiri \& Jafari, } 2017 \text { [41]; Adewumi, } 2002 \text { [42]; Cluff et al., } \\
2014 \text { [31]; Warner et al., } 2014 \text { [32]; Gregory et al., } 2011 \text { [33] }\end{array}$ \\
\hline Boron & ND - 95 & $\begin{array}{l}\text { Fillo \& Evans, } 1990 \text { [38]; Tibbetts et al., } 1992 \text { [30]; Cluff et al., } 2014 \text { [31]; } \\
\text { Warner et al., } 2014 \text { [32]; Gregory et al., } 2011 \text { [33]; Yeung et al., } 2011 \text { [34]; } \\
\text { Utvik et al., } 1999 \text { [35]; Alley et al., } 2011 \text { [36]; Khan et al., } 2016 \text { [37] }\end{array}$ \\
\hline Bromide & $150-1149$ & Fillo \& Evans, 1990 [38]; Wandera et al., 2011 [43]; Fillo et al., 1992 [44] \\
\hline Cadmium & $<0.005-1.21$ & Fillo \& Evans, 1990 [38]; USEPA, 2000 [29]; Tibbetts et al., 1992 [30] \\
\hline
\end{tabular}




\begin{tabular}{|c|c|c|}
\hline Calcium & ND - 74,185 & $\begin{array}{l}\text { USGS, } 2002 \text { [40]; Adewumi, } 2002 \text { [42]; Cluff et al., } 2014 \text { [31]; Warner et al., } \\
2014 \text { [32]; Gregory et al., } 2011 \text { [33]; Yeung et al., } 2011 \text { [34]; Utvik et al., } 1999 \\
\text { [35]; Alley et al., } 2011 \text { [36] }\end{array}$ \\
\hline Chloride & $2-254,923$ & $\begin{array}{l}\text { USGS, } 2002 \text { [40]; Adewumi, } 2002 \text { [42]; Cluff et al., } 2014 \text { [31]; Warner et al., } \\
2014 \text { [32]; Gregory et al., } 2011 \text { [33]; Yeung et al., } 2011 \text { [34]; Utvik et al., } 1999 \\
\text { [35]; Alley et al., } 2011 \text { [36]; Fillo \& Evans, } 1990 \text { [38] }\end{array}$ \\
\hline Chromium & ND - 1.1 & $\begin{array}{l}\text { Fillo \& Evans, } 1990 \text { [38]; Tibbetts et al., } 1992 \text { [30]; Cluff et al., } 2014 \text { [31] } \\
\text { Warner et al., } 2014 \text { [32]; Gregory et al., } 2011 \text { [33] }\end{array}$ \\
\hline Cobalt & N/A & \\
\hline Copper & $<0.002-5$ & USEPA, 2000 [29]; Tibbetts et al., 1992 [30] \\
\hline Fluoride & N/A & \\
\hline Iodide & $3-120$ & Neff et al., 2011 [24] \\
\hline Iron & ND - 1100 & $\begin{array}{l}\text { Tibbetts et al. } 1992 \text { [30]; Fillo \& Evans, } 1990 \text { [38]; Cluff et al., } 2014 \text { [31]; } \\
\text { Warner et al., } 2014 \text { [32]; Gregory et al., } 2011 \text { [33]; Yeung et al., } 2011 \text { [34]; } \\
\text { Utvik et al., } 1999 \text { [35]; Alley et al., } 2011 \text { [36] }\end{array}$ \\
\hline Lead & $0.002-10.2$ & USEPA, 2000 [29]; Tibbetts et al., 1992 [30] \\
\hline Lithium & $3-235$ & $\begin{array}{l}\text { USEPA, } 2000 \text { [29]; Tibbetts et al., } 1992 \text { [30]; Cluff et al., } 2014 \text { [31]; Warner et } \\
\text { al., } 2014 \text { [32]; Gregory et al., } 2011 \text { [33]; Yeung et al., } 2011 \text { [34]; Utvik et al., } \\
1999 \text { [35]; Alley et al., } 2011 \text { [36]; Khan et al., } 2016 \text { [37] }\end{array}$ \\
\hline Magnesium & ND - 46,656 & $\begin{array}{l}\text { USGS, } 2002 \text { [40]; Tibbetts et al., } 1992 \text { [30]; Cluff et al., } 2014 \text { [31]; Warner et } \\
\text { al., } 2014 \text { [32]; Gregory et al., 2011 [33]; Yeung et al., } 2011 \text { [34]; Utvik et al., } \\
1999 \text { [35]; Alley et al., } 2011 \text { [36] }\end{array}$ \\
\hline Manganese & $<0.004-175$ & $\begin{array}{l}\text { Tibbetts et al., } 1992 \text { [30]; Cluff et al., } 2014 \text { [31]; Warner et al., } 2014 \text { [32]; } \\
\text { Gregory et al., } 2011 \text { [33]; Yeung et al., } 2011 \text { [34]; Utvik et al., } 1999 \text { [35]; Alley } \\
\text { et al., } 2011 \text { [36] }\end{array}$ \\
\hline Mercury & $<0.001-0.002$ & Tibbetts et al., 1992 [30] \\
\hline Molybdenum & N/A & \\
\hline Nickel & $<0.08-9.2$ & USEPA, $2000[29]$ \\
\hline Nitrogen, ammoniacal & $10-300$ & Tibbetts et al., 1992 [30] \\
\hline Nitrate & $\mathrm{N} / \mathrm{A}$ & \\
\hline Palladium & $0.008-0.88$ & Tibbetts et al., 1992 [30]; Ekins et al., 2006 [39]; Bhadja et al., 2012 [45] \\
\hline Potassium & $0-14,840$ & $\begin{array}{l}\text { USGS, } 2002 \text { [40]; Cluff et al., } 2014 \text { [31]; Warner et al., } 2014 \text { [32]; Gregory et al., } \\
2011 \text { [33]; Yeung et al., } 2011 \text { [34]; Utvik et al., } 1999 \text { [35]; Alley et al., } 2011 \text { [36] }\end{array}$ \\
\hline Selenium & $0.03-0.04$ & Hardi et al., 2019 [46] \\
\hline Silver & $<0.001-7$ & USEPA, 2000 [29]; Tibbetts et al., 1992 [30] \\
\hline Sodium & $1-150.000$ & $\begin{array}{l}\text { Ricceri et al., } 2019 \text { [47]; Tibbetts et al., } 1992 \text { [30]; Adewumi, } 2002 \text { [42]; Alley et } \\
\text { al., } 2011 \text { [36]; Utvik et al., } 1999 \text { [35]; Yeung et al., } 2011 \text { [34]; Khan et al., } 2016 \\
\text { [37]; Cluff et al., } 2014 \text { [31]; Warner et al., } 2014 \text { [32]; Gregory et al., } 2011 \text { [33] }\end{array}$ \\
\hline Strontium & $0.02-6250$ & $\begin{array}{l}\text { Fillo \& Evans, } 1990 \text { [38]; Tibbetts et al., } 1992 \text { [30]; Alley et al., } 2011 \text { [36]; Utvik } \\
\text { et al., } 1999 \text { [35]; Yeung et al., } 2011 \text { [34]; Khan et al., } 2016 \text { [37]; Cluff et al., } \\
2014 \text { [31]; Warner et al., } 2014 \text { [32]; Gregory et al., } 2011 \text { [33] }\end{array}$ \\
\hline
\end{tabular}




\section{Continued}

\begin{tabular}{|c|c|c|}
\hline Sulfate & ND - 14,900 & $\begin{array}{l}\text { USGS, } 2002 \text { [40]; Adewumi, } 2002 \text { [42]; Alley et al., } 2011 \text { [36]; Utvik et al., } 1999 \\
\text { [35]; Yeung et al., } 2011 \text { [34]; Khan et al., } 2016 \text { [37]; Cluff et al., } 2014 \text { [31]; } \\
\text { Warner et al., } 2014 \text { [32]; Gregory et al., } 2011 \text { [33]; Johnson et al., } 2008 \text { [48]; } \\
\text { Shepherd et al., } 1992 \text { [49]; Ayers and Parker, } 2001 \text { [50]; McIntosh et al., } 2002 \\
\text { [51]; McIntosh and Walter, } 2005 \text { [52] }\end{array}$ \\
\hline Tin & ND - 1.1 & Fillo \& Evans, 1990 [38]; Fillo et al., 1992 [44] \\
\hline Titanium & $<0.01-0.7$ & $\begin{array}{l}\text { Tibbetts et al., } 1992 \text { [30]; Cluff et al., } 2014 \text { [31]; Warner et al., } 2014 \text { [32]; } \\
\text { Gregory et al., } 2011 \text { [33] }\end{array}$ \\
\hline Uranium & N/A & \\
\hline Vanadium & N/A & \\
\hline Zinc & $0.01-35$ & $\begin{array}{l}\text { Tibbetts et al., } 1992 \text { [30]; Alley et al., } 2011 \text { [36]; Utvik et al., } 1999 \text { [35]; Yeung } \\
\text { et al., } 2011 \text { [34]; Cluff et al., } 2014 \text { [31]; Warner et al., } 2014 \text { [32]; Gregory et al., } \\
2011 \text { [33] }\end{array}$ \\
\hline
\end{tabular}

The quantity and quality of PW highly depend on where, when and how hydrocarbons are produced. This leads to differences between PW samples and a high variability from one sampling site to another. Salinity or salt concentration, described as TDS, can vary in conventional oil and gas well produced waters from $1000-400,000 \mathrm{mg} / \mathrm{L}$ [28]. Typical values for elemental ion content are listed in Table 1.

Table 2 gives the contents and properties of a typically produced water sample from Kuwait. It shows that the ion concentration is on the higher side when compared to typically produced water samples from around the world. High ion concentrations in produced water limit the choice of treatment regime.

Oil and grease concentrations in $\mathrm{PW}$ can range from 2 to $565 \mathrm{mg} \cdot \mathrm{L}^{-1}$ [30]. Table 3 shows the ranges possible for organic content in PW. In general, PW discharges from offshore oil and gas platforms are a significant source of polycyclic aromatic hydrocarbons (PAHs) released to the ocean. PAH content in operational discharges from the offshore industry is a constant worry as many of the PAHs are both toxic and lipophilic so that they can be adsorbed by marine organisms and concentrate along the food chain. Already in 1996, it was estimated that in Norwegian operation about 25 tons of PAHs were released into North Sea waters [54]. In 2017, the number was given as 129 tons PAH discharge from all oil and gas operations on the Norwegian continental shelf (NCS), which makes up $0.306 \%$ of the total composition of the $1.3 \times 10^{8} \mathrm{~m}^{3} \mathrm{PW}$ discharged on NCS [55] [56]. Although PAHs are persistent organic pollutants (POPs), these compounds tend to biodegrade in the marine environment, where biodegradation makes them less lipophilic and thus less likely to accumulate in the marine food web [57]. Table 4 gives the breakdown of the PAH contents in PW from offshore operations from the Gulf of Mexico and offshore operations from the eastern and western regions of the North Atlantic [58].

Nonbiodegraded PAHs tend to concentrate in the sediments of water bodies. Table 5 gives data on the PAH content in sediments in the Arabian Gulf (Qatar 
Table 2. Properties of an analyzed produced water sample from Kuwait.

\begin{tabular}{|c|c|c|c|c|c|}
\hline \multicolumn{6}{|c|}{ Water API Analysis } \\
\hline TEST & UNIT & $1 \mathrm{~A}$ & $1 \mathrm{~B}$ & $2 \mathrm{~A}$ & $2 B$ \\
\hline Potassium (K) & ppm & 3805.22 & 3639.25 & 3942.65 & 3591.45 \\
\hline Magnesium (Mg) & ppm & 3519.39 & 3450.19 & 3628.65 & 3287.70 \\
\hline Sodium $(\mathrm{Na})$ & ppm & $75,802.85$ & $74,994.99$ & $77,968.81$ & $70,137.07$ \\
\hline Calcium (Ca) & ppm & $19,465.16$ & $18,964.52$ & $19,664.55$ & $17,807.94$ \\
\hline Strontium (Sr) & ppm & 471.24 & 512.23 & 484.66 & 434.71 \\
\hline Barium (Br) & ppm & 3.31 & 3.28 & 3.34 & 2.86 \\
\hline Iron $(\mathrm{Fe})$ & ppm & 0.47 & 0.46 & 0.57 & 0.52 \\
\hline Boron (B) & ppm & 30.37 & 30.95 & 30.46 & 28.69 \\
\hline Lithium (Li) & ppm & 7.01 & 6.71 & 6.88 & 5.92 \\
\hline Silicon $(\mathrm{Si})$ & ppm & 2.75 & 3.07 & 2.52 & 2.63 \\
\hline Chloride $\left(\mathrm{Cl}^{-}\right)$ & ppm & $153,037.65$ & $152,854.36$ & $149,487.52$ & $150,038.46$ \\
\hline Sulfate $\left(\mathrm{SO}_{4}^{2-}\right)$ & ppm & 380.00 & 380.00 & 390.00 & 390.00 \\
\hline $\mathrm{pH}$ & & 6.43 & 6.50 & 6.49 & 6.42 \\
\hline $\begin{array}{c}\text { Bicarbonate } \\
\left(\mathrm{HCO}_{3}^{-}\right) \text {alkalinity }\end{array}$ & ppm & 113.90 & 92.50 & 88.80 & 92.50 \\
\hline Resistivity@25ㅇ & $\mathrm{ohmS} / \mathrm{cm}$ & 2.44 & 3.28 & 12.11 & 12.08 \\
\hline Conductivity & $\mathrm{mS} / \mathrm{cm}$ & 409.00 & 305.00 & 82.60 & 82.75 \\
\hline Salinity as $\mathrm{NaCl}$ & ppm & $252,000.00$ & $254,000.00$ & $257,000.00$ & $258,000.00$ \\
\hline TDS (calculated) & ppm & $173,518.28$ & $172,854.57$ & $170,165.80$ & $168,810.65$ \\
\hline Density@ $25^{\circ} \mathrm{C}$ & $\mathrm{gm} / \mathrm{cm}^{3}$ & 1.00770 & 1.00780 & 1.01970 & 1.01950 \\
\hline
\end{tabular}

Table 3. Typical organic content of PW (in mg/L).

Total organic acids

Total saturated hydrocarbons

Total benzene, toluene, ethylbenzene, and xylenes (BTEX)

Total polycyclic aromatic hydrocarbons $(\mathrm{PAH})$

Total steranes/triterpanes

Ketones

Total phenols (primarily C0-C5-phenols) $\leq 0.001$ - 10,000 Neff et al., 2011 [24]; 2002 [53]

17 - $30 \quad$ Neff et al., 2011 [24]; 2002 [53]

0.068 - 578 Neff et al., 2011 [24]; 2002 [53]

$0.04-3.0 \quad$ Neff et al., 2011 [24]; 2002 [53]

$0.14-0.175$ Neff et al., 2011 [24]; 2002 [53]

1.0 - 2.0 Neff et al., 2011 [24]; 2002 [53]

$0.4-23 \quad$ Neff et al., 2011 [24]; 2002 [53]

and Kuwait) and the Red Sea (Saudi Arabia). The structural representation of the most common PAHs released in offshore operations is found in Scheme 1. Two-ringed PAHs such as naphthalenes and to a lesser degree three-ringed PAHs as anthracenes and phenanthrenes (Scheme 1) can dissolve in water, making them more available for biological uptake, but also making them more susceptible to 
Table 4. Breakdown of the PAH contents in PW from offshore operations from the Gulf of Mexico and offshore operations from the eastern and western regions of the North Atlantic.

\begin{tabular}{|c|c|c|c|c|c|}
\hline $\begin{array}{c}\text { Polycyclic aromatic } \\
\text { hydrocarbon } \\
\text { (conc. given in } \mu \mathrm{g} / \mathrm{L} \text { ) }\end{array}$ & $\begin{array}{c}\text { Platform } \\
\text { EB165A Gulf } \\
\text { of Mexico } \\
(1995)\end{array}$ & $\begin{array}{c}\text { Platform } \\
\text { GC19A Gulf } \\
\text { of Mexico } \\
\text { (1995) }\end{array}$ & $\begin{array}{c}\text { North Sea } \\
\text { Sampling } \\
\text { (Norwegian } \\
\text { sector, 1997) }\end{array}$ & $\begin{array}{l}\text { Grand } \\
\text { Banks } \\
\text { (Hibernia } \\
\text { oil field) }\end{array}$ & $\begin{array}{l}\text { Scotian } \\
\text { Shelf } \\
\text { (Thebaud } \\
\text { field) }\end{array}$ \\
\hline Naphthalene & 12.5 & 9.7 & 350 & 131 & 1512 \\
\hline C1-naphthalenes & 9.6 & 7.7 & 260 & 186 & 499 \\
\hline C2-naphthalenes & 5.7 & 6.7 & 150 & 163 & 92 \\
\hline C3-naphthalenes & 2.85 & 3.8 & 100 & 97.2 & 17 \\
\hline C4-naphthalenes & & & & 54.1 & 3.0 \\
\hline Acenaphthylene & 0.09 & 0.0185 & nd & 2.3 & 1.3 \\
\hline Acenaphthene & 0.009 & 0.038 & 1.8 & nd & nd \\
\hline Biphenyl & & & & nd & nd \\
\hline Fluorene & 0.135 & 0.23 & 8.9 & 16.5 & 13 \\
\hline Phenanthrene & 0.135 & 0.25 & 16.4 & 29.3 & 4.0 \\
\hline C1-phenanthrenes & & & 20.3 & 45.0 & 1.30 \\
\hline C2-phenanthrenes & & & 6.3 & 37.1 & 0.55 \\
\hline C3-phenanthrenes & & & 7.9 & 24.4 & 0.37 \\
\hline Dibenzothiophene & 0.079 & 0.265 & 2.5 & & \\
\hline C1-dibenzothiophenes & 0.19 & 0.5 & 5.7 & & \\
\hline C2-dibenzothiophenes & 0.355 & 0.845 & 6.1 & & \\
\hline C3-dibenzothiophenes & 0.365 & 0.87 & 3.2 & & \\
\hline Fluoranthene & 0.001 & 0.009 & 0.4 & 0.51 & 0.39 \\
\hline Pyrene & 0.014 & 0.017 & 0.7 & 0.94 & 0.36 \\
\hline Benz(a)anthracene & & & 0.6 & 0.60 & 0.32 \\
\hline Chrysene & nd & 0.005 & 0.5 & 3.6 & nd \\
\hline Perylene & & & & nd & nd \\
\hline Benzo(b)fluoranthene & & & & 0.61 & nd \\
\hline Benzo(k)fluoranthene & & & 0.2 & nd & nd \\
\hline Benzo(a)pyrene & nd & 0.001 & 0.2 & 0.38 & nd \\
\hline Benzo(e)pyrene & & & & 0.83 & nd \\
\hline Benzo(g,h,i)perylene & nd & 0.0015 & 0.2 & 0.17 & nd \\
\hline Dibenz(a,h)anthracene & & & & 0.21 & nd \\
\hline Indeno(1,2,3-cd)pyrene & & & & nd & nd \\
\hline
\end{tabular}


Table 5. Data on the PAH content in sediments in the Arabian Gulf (Qatar and Kuwait) and the Red Sea (Saudi Arabia).

\begin{tabular}{|c|c|c|c|c|c|}
\hline \multirow{2}{*}{$\begin{array}{c}\text { Polycyclic aromatic } \\
\text { hydrocarbon in sediments at } \\
\text { different locations on the } \\
\text { Arabian peninsula } \\
\text { (conc. given in } \mathrm{ng} / \mathrm{L})\end{array}$} & \multicolumn{3}{|c|}{$\begin{array}{l}\text { Coastal sediments of the } \\
\text { exclusive economic zone } \\
\text { (EEZ) of Qatar [59] }\end{array}$} & \multirow{2}{*}{$\begin{array}{c}\text { Coastal } \\
\text { sediment near } \\
\text { Shuaiba } \\
\text { harbor, Kuwait } \\
\text { [60] }\end{array}$} & \multirow{2}{*}{$\begin{array}{c}\text { Coastal } \\
\text { sediment } \\
\text { (ng/g), Jeddah, } \\
\text { Saudi Arabia } \\
{[61]}\end{array}$} \\
\hline & $\begin{array}{l}\text { conc. } \\
\text { (ng/L) }\end{array}$ & $\max$ & $\min$. & & \\
\hline Naphthalene & $3.6 \pm 7.7$ & 31.0 & 0.3 & $0-4.38$ & $8.8-60.3$ \\
\hline 1-Methylnaphthalene & $1.3 \pm 2.8$ & 11.2 & 0.1 & nd & nd \\
\hline 2-Methylnaphthalene & $2.1 \pm 4.9$ & 19.9 & 0.2 & nd & nd \\
\hline C1-naphthalenes & $3.4 \pm 7.6$ & 31.1 & 0.3 & $0.04-5.23$ & nd \\
\hline C2-naphthalenes & $7.6 \pm 12.0$ & 42.2 & 0.3 & $0.06-16.69$ & nd \\
\hline C3-naphthalenes & $9.7 \pm 17.4$ & 65.6 & 0.0 & $0 .-20.28$ & nd \\
\hline C4-naphthalenes & $10.9 \pm 32.8$ & 132.2 & 0.0 & nd & nd \\
\hline Acenaphthylene & $0.04 \pm 0.1$ & 0.3 & 0.0 & nd & $12.5-86.3$ \\
\hline Acenaphthene & $0.03 \pm 0.1$ & 0.5 & 0.0 & nd & $38.0-142.0$ \\
\hline Biphenyl & $1.3 \pm 1.0$ & 4.2 & 0.5 & nd & nd \\
\hline Fluorene & $0.1 \pm 0.2$ & 0.8 & 0.0 & $0-6.21$ & $17.7-89.4$ \\
\hline Phenanthrene & $0.8 \pm 1.2$ & 4.6 & 0.1 & $0.49-95.9$ & $90.5-292.2$ \\
\hline C1-phenanthrenes/anthracenes & $2.6 \pm 6.6$ & 25.1 & 0.0 & $0-46.82$ & nd \\
\hline C2-phenanthrenes/anthracenes & $8.3 \pm 25.1$ & 99.2 & 0.0 & $2.64-107.5$ & nd \\
\hline C3-phenanthrenes/anthracenes & $7.2 \pm 20.2$ & 77.5 & 0.0 & nd & nd \\
\hline C4-phenanthrenes/anthracenes & $4.8 \pm 13.3$ & 51.5 & 0.0 & nd & nd \\
\hline Dibenzothiophene & $0.3 \pm 0.7$ & 2.8 & 0.0 & $0-10.51$ & nd \\
\hline C1-dibenzothiophenes & $1.4 \pm 3.9$ & 15.3 & 0.0 & $0.63-48.41$ & nd \\
\hline C2-dibenzothiophenes & $4.2 \pm 12.1$ & 47.6 & 0.0 & nd & nd \\
\hline C3-dibenzothiophenes & $13.4 \pm 40.3$ & 157.5 & 0.0 & nd & nd \\
\hline Fluoranthene & $1.1 \pm 1.7$ & 6.6 & 0.1 & $0.11-292.57$ & $199.3-1066$ \\
\hline Pyrene & $1.0 \pm 1.4$ & 5.0 & 0.1 & $0.52-185.42$ & $268.7-788.7$ \\
\hline Benz(a)anthracene & $0.6 \pm 0.8$ & 2.9 & 0.0 & 0.60 & $39.0-184.6$ \\
\hline Chrysene & $0.8 \pm 1.2$ & 4.4 & 0.1 & nd & $286.0-710.7$ \\
\hline C1-chrysene & $0.7 \pm 1.5$ & 5.5 & 0.0 & nd & nd \\
\hline C2-chrysene & $1.1 \pm 2.1$ & 7.8 & 0.0 & nd & nd \\
\hline C3-chrysene & $0.7 \pm 1.2$ & 4.2 & 0.0 & nd & nd \\
\hline C4-chrysene & $0.4 \pm 0.6$ & 1.8 & 0.0 & nd & nd \\
\hline Perylene & $0.2 \pm 0.2$ & 0.8 & 0.0 & nd & nd \\
\hline Benzo(b)fluoranthene & $0.9 \pm 1.3$ & 4.5 & 0.0 & $0.19 c^{2}$ & $0.0-100.5$ \\
\hline Benzo(k)fluoranthene & $0.4 \pm 0.5$ & 1.8 & 0.0 & $0-199.13$ & $0.0-27.7$ \\
\hline Benzo(a)pyrene & $0.5 \pm 0.7$ & 2.4 & 0.0 & $0-94.75$ & $104.0-476.7$ \\
\hline Benzo(e)pyrene & $0.7 \pm 0.9$ & 3.4 & 0.0 & nd & nd \\
\hline Benzo(g,h,i)perylene & $0.8 \pm 1.0$ & 3.7 & 0.0 & nd & $0.0-48.5$ \\
\hline Dibenz(a,h)anthracene & $0.2 \pm 0.3$ & 0.8 & 0.0 & nd & 0.0 \\
\hline
\end{tabular}




\section{Continued}

\begin{tabular}{cccccc} 
Indeno(1,2,3-cd)pyrene & $0.6 \pm 0.7$ & 2.3 & 0.0 & nd & $0.0-16.5$ \\
Fluorene & $0.1 \pm 0.2$ & 0.8 & 0.0 & $0-0.62$ & $17.7-89.4$ \\
C1-fluorenes & $3.1 \pm 8.4$ & 33.9 & 0.0 & nd & nd \\
C2-fluorenes & $5.3 \pm 14.6$ & 58.5 & 0.0 & nd & nd \\
C3-fluorenes & $8.9 \pm 26.9$ & 107.2 & 0.0 & nd & nd \\
\hline
\end{tabular}<smiles>C1=Cc2cccc3cccc1c23</smiles>

Acenaphthylene<smiles></smiles>

Fluoranthene<smiles></smiles>

Benzo[b]fluoranthene<smiles>c1cc2c3c(cccc3c1)CC2</smiles>

Acenaphthene<smiles></smiles>

Pyrene<smiles>c1ccc2cc3ccccc3cc2c1</smiles>

Anthracene<smiles>c1ccc2c(c1)ccc1ccccc12</smiles>

Phenanthrene<smiles></smiles>

Perylene<smiles>c1ccc2cc3c(cc2c1)-c1cccc2cccc-3c12</smiles>

Benzo[k]fluoranthene<smiles>c1ccc2cc3c(ccc4ccccc43)cc2c1</smiles>

Dibenz[ah]anthracene

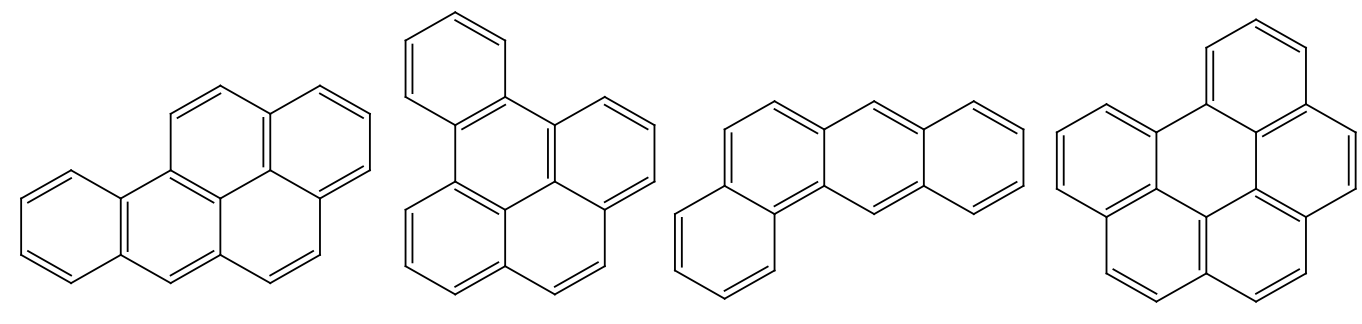

Benzo[a]pyrene

Benzo[e]pyrene

Benz[a]anthracene

Benzo[ghi]perylene<smiles>c1ccc2c(c1)Cc1ccccc1-2</smiles><smiles>c1ccc2c(c1)sc1ccccc12</smiles><smiles>c1ccc(-c2ccccc2)cc1</smiles>

Biphenyl<smiles>Cc1cccc2ccccc12</smiles>

1-Methylnaphthalene<smiles>Cc1ccc2ccccc2c1</smiles>

2-Methylnaphthalene

Scheme 1. Structures of the most common PAHs released in offshore operations. 
degradation. On the other hand, four-ringed and five-ringed PAHs such as benzopyrenes are not soluble in water, but they tend to biodegrade much more slowly in the aquatic environment than less extended aromatic systems. Benzo[a]pyrene (Scheme 1) leads to mutagenic metabolites and itself is listed as a group 1 carcinogen by the International Agency for Research on Cancer. Benzo(ghi)perylene is deemed to be mutagenic as well as a carcinogen. It accumulates readily in aquatic organisms.

As produced water from oil and gas exploration may contain different types of contaminants at various concentrations, various treatment technologies have been proposed to deal with produced water. Often, up to $80 \%$ of the $\mathrm{PW}$ is re-injected into the oil well in order to maintain the pressure in the well and to manage large amounts of accumulating PW. In water-scarce regions such as on the Arabian Peninsula, it would be attractive to utilize PW for irrigation. Again, re-injection and utilizing PW for irrigation would necessitate different levels of water purity and would result in different treatment regimes. The quality requirements of the water used for re-injection depend on the permeability of the oil reservoir; thus, in fractured oil reservoirs, the water can move more freely leading to reduced clogging of the reservoir's pores. On- and off-shore operations differ in that off-shore operations often have added space constraints and need to deal with the fact that in many regions water discharged into the sea after treatment should have no more than $40 \mathrm{ppm}$ non-water soluble hydrocarbon content, with a further reduction seen in the future [23]. In fact, at the Oslo Paris Convention (OSPAR) it was agreed that the maximum discharge is to be reduced to $30 \mathrm{ppm}$ OIW (oil in water) and that the overall oil discharges in PW be reduced by $15 \%$ from the levels found in 1999 [23]. In addition, more attention is given to the more soluble organic compounds found in PW, some of which show appreciable toxicity to the aquatic environment. This may lead to an even higher focus on reinjection of produced water in offshore operations. Regardless, produced water treatment on offshore operations allows for a smaller footprint than onshore operations would do. Thus, overall, off-shore [62] [63] and on-shore operations often favor different PW purification set-ups. For onshore operations, these can include physical, chemical and biological methods [64] and often a combination thereof, while for offshore operations biological treatment processes are often untenable due to their large environmental footprint [65]. Some of these treatment methods are listed and discussed below.

\section{Treatment Methods}

\subsection{Physical Methods}

Physical methods include gravity separation, adsorption, the use of hydrocyclone separators, membrane filtration-based techniques, including osmosis processes and thermal evaporators [66].

\subsubsection{Gravity Separation (as Primary Treatment)}

Many of the most common treatment methods of PW rely on gravity to separate 
the oil from water. In fact, a general practice in use for PW treatment has been gravity-based separation and discharge into the environment [23]. Already the three-phase separator at the well head that separates the well fluid into oil, gas and water works on gravity separation. Other gravity separation methods include the use of the API (American Petroleum Institute) gravity separator and the corrugated plate interceptor (CPI)//parallel plate interceptor separators (PPI). The operation of API gravity separators is based on the specific gravity difference between the oil and the wastewater. That difference is much smaller than the specific gravity difference between the suspended solids and water. Suspended solids will sink to the bottom of the separator, the oil will rise to the top, and the wastewater will form the middle layer. API separators can then not be used when the mean oil droplet size in the feed is less than 150 microns or the oil density is greater than $0.925 \mathrm{~kg} / \mathrm{L}$. Corrugated plate separators contain a series of plates through which the contaminated water flows. This allows the oil droplets in the water to coalesce on the underside of the plates, eventually forming larger oil droplets which float off the plates and accumulate at the top of the chamber. Therefore, these separators were also called plate coalescers. The first CPIs had plates parallel to the longitudinal axis of an API gravity separator. Oil droplets to be separated should not be smaller than 40 microns. The oil-watersediment separation can be enhanced by the use of ultrasound, microwaves, and electric and temperature fields, leading to what now is called enhanced gravity sedimentation [67] [68]. Continuous efforts are underway to optimize gravity separators as to their size and structure, where internal components lead to a further improvement of separation performance [69].

\subsubsection{Hydrocyclones and Centrifugal Separators (as Primary Treatment)}

A centrifugal separator separates oil and water by centrifugation. A cylindrical container rotates inside a larger stationary container, where water as the denser liquid accumulates at the periphery of the rotating container and is collected from the side of the device, whereas the less dense oil accumulates at the rotation axis and is collected from the center. In a hydrocyclone, PW coming from a primary separator is fed tangentially under pressure into inlet ports and spirals down a cylinder of reducing diameter. The ever more rapidly rotating oil-water mixture separates under centripetal forces, with water being of higher specific gravity collected at the lower outflow, and the oil, of lower specific gravity, being collected at the upper overflow. PW necessitates a residence time of only a few seconds in the hydrocyclone to be deoiled. This allows for a compact design of the hydrocyclone, making it suitable for offshore operations. It must be noted that in comparison to centrifugal separators hydrocyclones do not have moving parts. Judd et al. came to the conclusion that among typical advanced PW treatment methods, hydrocyclone technology has the smallest area footprint, where an individual hydrocyclone can process up to $440 \mathrm{~m}^{3} / \mathrm{h}$ of water per $\mathrm{m}^{2}$ footprint [65]. In recent times, a possible enhancement of the oil-water separation with hydrocyclones in the presence of electric and magnetic fields has been studied 
[70] [71]. Hydrocyclones are also used as sand separators [72]. The use of hydrocyclones for water-oil separation and for sand separation is very much in evidence in the Middle East [73].

\subsubsection{Induced Gas Flotation (IGF, as Secondary Treatment)}

In induced gas flotation (IGF), the removal of oil and other low density, hydrophobic contamination is realized by introducing gas bubbles into produced water in a flotation tank. The suspended matter adheres to the rising bubbles, causing it to float to the surface of the water, where it is removed by a skimming device. Due to explosion risk, in the oil industry, IGF units use natural gas or nitrogen instead of air that is usually used in normal wastewater treatment. IGFs are often used in offshore operations as their area footprint is relatively small. In some cases, an IGF unit follows the hydrocyclone oil-water separation, while in other cases gravity treatment of PW is directly followed by IGF [74]. A closely related separation technique is the dissolved gas flotation (DGF), where oil and water are pre-saturated with gas and the pressure of the system is reduced. This leads to the generation of smaller sized bubbles $(10-100 \mu \mathrm{m})$ than is the case with IGFs $(100-1000 \mu \mathrm{m})$. Retention time of PW in the separators differs, with $<5$ min retention time given for IGFs and $5-15$ min given for DGFs [74]. Also, the efficiency of oil-water separation differs, with IGFs usually having the better oil removal efficiency [75]. For offshore operations, so-called compact flotation units (CFUs) have been developed. These can operate in dual mode, after an IGF type separation, the residual flotation gas is released in a secondary separation stage, mimicking a DGF. Thus, oil droplets much smaller than $100 \mu \mathrm{m}$ (DGF) and oil droplets larger than $100 \mu \mathrm{m}$ (IGF) can be floated [76]. The CFUs have no moving parts. Capacities can be $10-900 \mathrm{~m}^{3} / \mathrm{h}$ with residence times of $0.5-1 \mathrm{~min}$ [74].

\subsubsection{Adsorption Processes (as Secondary or Tertiary Treatment)}

In principle, both metal contents as well as organic components, both BTEX and oil of PW can be withheld by a solid adsorbent. When used, an adsorption process is a unit within a treatment train rather than a stand-alone treatment method. While adsorption process units can withhold over $80 \%$ of the heavy metals [77] and can lead to virtually $100 \%$ water recovery [16], there are issues of overloading the sorbent and the necessity of treatment of the spent sorbent material. Regarding the first issue, adsorption units are often used as a polishing step where the relative concentrations of contaminants are low. As to the treatment of the spent sorbent, if a recycling/regeneration does not offer itself, it needs to be disposed of as waste. Regeneration of the sorbent invariably leads to liquid waste. Sorbents can be inorganic minerals such as clays, they can be synthetic inorganic materials such as zeolites or alumina, they can inorganicorganic hybrids such as organoclays or they can be activated carbons. One such adsorbent is granulated activated carbon which can have surface areas of up to $1000 \mathrm{~m}^{2} / \mathrm{g}$ [16]. In fact, activated carbon still serves as the benchmark for the 
evaluation of other sorbents. Commercial activated carbon has been found to adsorb $730 \mathrm{mg}$ oil per $\mathrm{g}$ of sorbent [78]. Nevertheless, much research has been devoted to the development of new sorbents for PW treatment [79] that include zeolites [80]. This includes the use of sepiolite modified with surfactants (985 $1013.5 \mathrm{mg}$ oil/g adsorbent [81]), attapulgite (155 mg oil/g adsorbent [79]) and bentonite (38.5 $\mathrm{mg}$ hydrocarbon/g adsorbent [82] [83]) for the separation of oil from synthetic PW. Carbon based sorbents include biowastes such as pomegranate [84] and banana peel [85] and date seeds [86] as well as chitosan [87] which can be seen as waste from the shrimping industry. Often, nutshell filters have been used as a polishing step [88], where typically walnut shell or pecan nut shell are used [89]. Also, pyrolyzed wastes have been used as sorbents in these filtration steps such as wood biochar (114 - $148 \mathrm{mg}$ OC/g sorbent [90]). These adsorption techniques usually play out in form of filtration columns. Induced gas flotation, coagulation-flocculation techniques and treatment of PW in constructed wetlands have an adsorption component within their processes, but they are introduced under separate headings under physical, chemical and biological methods.

\subsubsection{Membrane Filtration (as Secondary or Tertiary Treatment)}

Membrane filtration is an important water purification technique used in wastewater treatment and water desalination and is also started to be used in the treatment of PW [91] [92] [93]. The water is pushed through porous membranes, whereas particulate matter is filtered off. One has to distinguish among four established membrane separation processes, namely microfiltration (MF), ultrafiltration (UF), nanofiltration (NF) and reverse osmosis, where the pore sizes of the membranes become smaller in the order of MF ( 0.1 micron $)>$ UF $(0.01 \mathrm{mi}-$ cron $)>\mathrm{NF}(0.001$ micron $)>\mathrm{RO}(0.001$ micron $)$. The smaller the pore size of the membrane the higher is the operating pressure of the filtration process, from 1 5 bar for MF, 1 - 7 bar for UF, 5 - 10 bar for NF to 15 - 70 bar for RO. MF and UF filtration is based on convective pore-flow mechanism (Darcy's law), RO on the solution diffusion mechanism (Fick's law). In NF, both processes operate, often side-by-side. Usually, NF membranes reject di- and multivalent ions such as $\mathrm{Mg}^{2+}, \mathrm{Ca}^{2+}, \mathrm{Al}^{3+}$, and $\mathrm{SO}_{4}^{2-}$, but let monovalent ions such as $\mathrm{Na}^{+}$and $\mathrm{Cl}^{-}$pass through, while $\mathrm{RO}$ in principle rejects all charged particles. Then, within reasonable cost, filtration operations are set in such a way that filtration through larger pore membranes is followed by a filtration through smaller pore membranes, to minimize fouling problems. Thus, micro-filtration (MF) and ultrafiltration (UF) can be used as a pre-treatment to remove total suspended solids (TSS) and oil/grease before (reverse) osmosis or other desalting processes [94] [95]. A typical example is the pretreatment of oil sands process-affected water (OSPW), where due to its complex composition, physical and physicochemical pre-treatments are needed to remove suspended solids that include gravity separation, centrifugal settling, granular media filtration, coagulation-flocculationsedimentation or microfiltration [96]. Here, low pressure membrane filtration, 
such as microfiltration (MF), has been forwarded to be advantageous because of its relatively low cost and energy consumption and because of the high quality effluent it delivers [97].

One of the first membrane setups used for the separation of oil from water used ceramic membranes and polyacrylonitrile (PAN) membranes [98]. Nowadays, both ceramic [99] and polymeric (eg., made of polyolefins or of fluorinated polymers [100]). MF membranes as well as composite membranes [101] are used for the treatment of PW. Ceramic membranes offer advantages in that they are little affected by acids, bases, oxidants and by the temperature of PW. A number of studies have been carried out on ceramic membranes with synthetic samples [102] [103]. In this regard, ceramic membranes of different compositions have been tested in PW treatment, including silicon carbide-alumina membranes, made by low pressure chemical vapor deposition using $\mathrm{SiH}_{2} \mathrm{Cl}_{2}$ and $\mathrm{C}_{2} \mathrm{H}_{2} / \mathrm{H}_{2}$ at $750^{\circ} \mathrm{C}$ [104], mullite and mullite-alumina membranes, prepared from kaolin and $\alpha$-alumina with a calcination step at $1250^{\circ}$ [105], and graphene oxide modified alumina membranes [106]. In 2010, it was maintained that the industrial use of ceramic membranes for oilfield produced water treatment was still limited, due to investment cost and lack of operational experience on a large scale [107]. In 2015, Weschenfelder approximated the operational cost and capital expenditure for a plant capable of generating $1000 \mathrm{~m}^{3} / \mathrm{h}$ of permeate to be equal to US $\$ 0.27 / \mathrm{m}^{3}$ and US\$ 7.11 million, respectively [108]. Nevertheless, the use of ceramic membranes in treatment of OSPW was formulated by Dong et al. [109]. Also, nanofiltration [110] and ultrafiltration ceramic membranes are being considered an improvement for designing more efficient treatment processes for oil and gas PW, including for new offshore installation units [111].

Weschenfelder et al. [111] have commented on the influence on ceramic membrane performance of polymer additives that have been used to promote enhanced oil recovery by increasing the viscosity of the water injected into the reservoirs. Even at a concentration of $0.1 \mathrm{~g}$ polymer/L PW, the polymer has a significant impact on the membrane flux, leading to a reduction of $84 \%$ from the initial permeation flux after $40 \mathrm{~min}$. of operation. It must also be noted that polymer addition in EOR processes can cost $\$ 4-5$ per $\mathrm{m}^{3}$ injected water and that polymer consumption increases with the salinity of the injected water as the viscosifying polymers are polyelectrolytes that interact with salts and ionic surfactants. This is one more reason, why it is essential that the produced water is at least partially desalinated, if it is to be reinjected.

Membranes can be operated in one of two ways, either as dead-end filtration, in which the total feed is passed through the membrane as discussed above or as crossflow filtration (tangential flow filtration). In a crossflow filtration, the majority of the feed travels tangentially across the surface of the filter, rather than into the filter. The principal advantage of this is that the filter cake is for the most part washed away during the filtration process, increasing the length of time that the filter unit can be operational, leading to a continuous filtration 
process. A portion of the feed passes through the membrane as permeate; everything else is retained on the feed side of the membrane as retentate. Crossflow membrane filtration delivers treated water of consistent quality, but is deemed to have a relatively large are footprint [65]. Also, VESP (vibratory shear enhanced filtration process) membrane systems have been used for PW filtration [112]. The pressure vessel moves in a vigorous vibratory motion, tangential to the membrane surface. This creates shear waves, preventing membrane fouling [112].

\subsubsection{Forward Osmosis (as Secondary Treatment)}

(Forward) osmosis is the spontaneous net movement or diffusion of solvent molecules, here water, through a semipermeable membrane from a region of low solute concentration to a region of high solute concentration, leading at some point to equalization of solute concentrations on the both sides. In produced water treatment, forward osmosis (FO) offers itself then, when produced water is in contact through a semipermeable membrane with an artificially produced aqueous solution of high salinity, called the draw solution (DS). As the osmotic separation proceeds, water leaves the produced water solution and starts diluting the draw solution. This process concentrates the produced water solution. Then, the draw solution is subjected to reverse osmosis, nanofiltration or membrane distillation. This leads to the creation of purified water on the one hand and re-concentrated DS on the other, which can be reused for further FO of PW. Initially, membranes for FO processes were produced of cellulose acetate (CA), cellulose triacetate (CTA), polysulfone (PS), or polyethersulfone (PES), or they were thin-film composite (TFC) membranes [113] [114]. These membrane materials possess some disadvantages, however, such as low permeability, low salt rejection and poor chemical stability. As in reverse osmosis, more and more polyamide based membranes are used nowadays. The search for the most appropriate salt for the draw solution (DS) is ongoing [115] [116]. Sodium chloride $(\mathrm{NaCl})$, sodium sulfate $\left(\mathrm{Na}_{2} \mathrm{SO}_{4}\right)$, ammonium sulfate $\left[\left(\mathrm{NH}_{4}\right)_{2} \mathrm{SO}_{4}\right]$, and magnesium chloride $\left(\mathrm{MgCl}_{2}\right)$ are typically used for their low replenishing costs. Also, ammonium bicarbonate $\left(\mathrm{NH}_{4} \mathrm{HCO}_{3}\right)$ is an interesting choice as it decomposes into ammonia $\left(\mathrm{NH}_{3}\right)$ and carbon dioxide $\left(\mathrm{CO}_{2}\right)$ at slightly elevated temperatures (i.e., at $60^{\circ} \mathrm{C}$ at atmospheric pressure [117]) and can thus be thermally recycled. While FO consumes much less energy than membrane filtrations under pressure and thermal purification processes, it must be kept in mind that significant energy is needed to separate DS after the osmosis process into purified water and recycled DS. This second process depends on the characteristics of DS used but not on the quality of PW itself. As with many membrane processes, fouling can be a problem [118].

\subsubsection{Reverse Osmosis (as Tertiary Treatment)}

Reverse osmosis (RO) involves a solvent diffusion across a semipermeable membrane that is either nonporous or has pores up to $0.6 \mathrm{~nm}$ in size. The major removal mechanism stems from the difference in solubility or diffusivity of the 
components, and the process is dependent on pressure, solute concentrations, and other parameters. Typically, RO membranes can be composed of a thin film composite (TFC) polyamide membrane consisting of three layers: a polyester web as structural support (120 - $150 \mu \mathrm{m}$ thick), a microporous interlayer (about $40 \mu \mathrm{m})$ and an ultra-thin barrier layer on the upper surface $(0.2 \mu \mathrm{m})$ [119]. The microporous interlayer is often made of polysulfone and is there to enable the barrier layer to withstand the high pressure applied (15 - 70 bar) to operate the system. The barrier layer then is made of an aromatic polyamide. The most extensively used design in RO desalination is the spiral wound membrane module configuration, which has a high specific membrane surface area. Other advantages of the spiral wound membrane are easy scale up, and low cost as it is the least expensive module configuration to produce from flat sheet TFC membranes [120]. So, it is not surprising that spiral wound polyamide membrane modules are the most commonly found for RO/NF operations. Asymmetric cellulose acetate (CA) hollow fiber membranes follow in second place [119]. Polyamide spiral wound RO modules have been surface-modified with polydopamine. Although originally intended to make the $\mathrm{RO}$ units more resistant towards fouling, a higher and more stable salt rejection was seen with these surfacemodified RO units [95]. RO and also UF/NF processes have problems treating produced water of very high salinity in contrast to some of the purification methods using membranes such as electrodialysis, forward osmosis (FO), and membrane distillation (MD). Additionally, membrane fouling including membrane scaling decreases the membrane's lifetime. Thus, in the case of using RO to treat PW from oil fields, pretreatment of PW and regular replacement of membranes add to the cost. Early studies have revealed that multistage pretreatment is also key to minimize the fouling of the $\mathrm{RO}$ membrane and that nanofiltration is the most promising pretreatment method [121]. The costs of treating brackish PW from Californian oilfields with RO combined with a suitable pretreatment to a level that it can be used for beneficial purposes has been calculated at $\$ 1.43 / \mathrm{m}^{3}-\$ 1.46 / \mathrm{m}^{3}$. This may be compared with the current cost of fresh water in California, which typically is in the range of $\$ 0.49 / \mathrm{m}^{3}-0.92 / \mathrm{m}^{3}$ [122].

\subsubsection{Electrodialysis (as Secondary Treatment)}

Another technique has been studied in regard to the desalination of produced water, namely electrodialysis (ED). In ED, ions are pushed from the feed stream through ion exchange membranes to separate brine streams, the driving force being an electric field that is set up by two electrodes. So, in this separation technique it is the ions that migrate through the membranes, cations towards the cathode, anions towards the anode, rather than the water itself as is the case in the other membrane separation techniques. Divalent cations and anions such as $\mathrm{Mg}^{2+}, \mathrm{Ca}^{2+}$, and $\mathrm{SO}_{4}^{2-}$ are more easily separated than monovalent ions such as $\mathrm{Na}^{+}$and $\mathrm{Cl}^{-}$[123]. $\mathrm{H}$. Yan et al. have proposed a multi-batch ED system prior to an evaporative crystallizer [124]. A significant advantage of ED is the relatively 
low energy consumption ( $7-15 \mathrm{kWh} / \mathrm{m}^{3}$ water) versus some of the thermal methods $\left(20-25 \mathrm{kWh} / \mathrm{m}^{3}\right.$ water for evaporative processes, ref. [125] and see below). Sosa-Fernandez et al. have looked at ED-based desalination and reuse, eg. as injection water, of brackish polymer-flooding PW [126]. Concentration polarization and fouling are two problems that need to be overcome with ED. Sosa-Fernandez et al. have shown that this can be achieved in part by applying a pulsed electric field [127]. ED systems have been combined with other treatment units such as with an RO system and a low-temperature crystallizer [128]. It is not sure whether ED can also be cost-effective for the treatment of concentrated PWs [129].

\subsubsection{Membrane Distillation (as Tertiary Treatment)}

Membrane Distillation (MD) is a thermally driven, vaporization-based desalination technique that can even be applied for desalinating water containing TDS > $70 \mathrm{~g} / \mathrm{L}$ [130]. That means it can still operate at TDS levels at which it would be difficult for RO processes to function. Although membrane distillation (MD) has historically resulted in lower permeate flux and high thermal energy consumption relative to other systems, new developments can lead the process to consume less energy than pressure-driven systems such as RO with lower fouling rates [131] [132] [133] [134]. Direct Contact Membrane Distillation (DCMD) is the most common MD-configuration, in which feed water, heated from an external source, is passed over a hydrophobic microporous membrane with cooled and purified permeate water flowing on the opposite side [131] [132] [135]. When the system is operating, the temperature difference created between feed and permeate waters manifests a trans-membrane vapor pressure gradient that drives water vapor through the membrane to condense in the permeate channel as pure water. The hydrophobic membrane only allows water vapor to permeate the membrane pores, concentrating dissolved solids, non-volatile solutes, and even radionuclides, in the liquid feed reservoir. Integrating MD operations into industrial processes [136] can help bring down the energy costs. Also, omniphobic membranes made of polyvinylidene fluoride (PVDF) have been used for the desalination of shale gas $\mathrm{PW}$ [137]. It is possible to use a solar absorber plate above the feed channel [138] to provide supplementary heating along the module length. Nanophotonics Enhanced Solar Membrane Distillation (NESMD) is a desalination technology developed through the Nanotechnology-Enabled Water Treatment (NEWT) program of the National Science Foundation that utilizes $100 \%$ renewable energy in the form of sunlight, to drive the distillation process. NESMD functions as does MD, but it uses a hydrophilic, microporous, carbon black nanoparticle-infused membrane coating on the hydrophobic membrane that scatters sun light and generates highly-localized photothermal heat. This helps vaporize water at the membrane interface, resulting in a reversal of temperature polarization and a reduction in heat loss (conductive and dissipative) in the feed water. The increase in the thermal efficiency of the NESMD configuration overcomes the thermodynamic limitations of conventional MD and permits 
higher permeate fluxes at lower flow rates and with larger membrane surface areas [139]. Said et al. [131] found that NESMD shows an excellent rejection both of the dissolved organic carbon (DOC) and dissolved solids (TDS) in oil produced waters. The hydrophilicity of the NESMD membrane Said et al. had developed could be recovered after washing it with de-ionized water [131].

Highly contaminated waters like PW have a high potential to foul and scale membranes, and for traditional porous distillation membranes, this can lead to pore-wetting and complete salt passage. Wang et al. have looked at the possibility to use a hybrid organic-ceramic hydrophilic pervaporation membrane, $\mathrm{HybSi}{ }^{\circ}$ PVM-039, comprised of cross-linked organo-silane selective layer casted on an $\alpha-\mathrm{Al}_{2} \mathrm{O}_{3}$ tubular ceramic membrane support, for the separation of lab-prepared saline and hypersaline waters, modeled after real oil and gas PWs. Pervaporation is a hybrid distillation process, with the separation performance being a function of the relative solubilities in the membrane of the components in the feed and their boiling points [140].

\subsection{Chemical Processes}

Chemical treatment processes include coagulation-flocculation, advanced oxidation processes and other disinfection procedures.

\subsubsection{Coagulation Flocculation (as Secondary Treatment)}

Coagulation flocculation is a purification technique that is used in general wastewater treatment. Oftentimes, the suspension of fine particles or droplets in water is quite stable as surface charges on the fine particles/droplets hinder these to aggregate or coalesce. The addition of a coagulant leads to destabilization of the system, partially through charge neutralization. This leads to aggregation of the fine particles and the coalescence of fine droplets by van der Waals forces that now supersede any remnant electrostatic repulsion between the particles. In addition, both particles and droplets may adsorb to the coagulant. This leads to the separation of the impurities from the aqueous phase, often through precipitation together with the coagulant. This co-precipitation is seen to be more advantageous than the adsorption of contaminants of produced water on already crystallized adsorbents as the contaminants become more easily entrapped in freshly crystallizing solid. A typical example is the removal of boron as contaminant in $\mathrm{PW}$ in a co-precipitation with magnesium chloride $\left[\mathrm{MgCl}_{2}\right]$. Another example is the addition of water soluble sodium silicate in the removal of contaminants from produced water stemming from a South Tunisian oil field. This procedure involving a co-precipitation/adsorption process led to a removal of organic matter and heavy metals of up to $97 \%$, where the silica and calcium silicate with the adsorbed contaminants were added to a landfill [141]. Typical coagulants in general wastewater treatment are aluminum sulfate $\left[\mathrm{Al}_{2}\left(\mathrm{SO}_{4}\right)_{3} \cdot 18 \mathrm{H}_{2} \mathrm{O}\right]$, sodium aluminate $\left[\mathrm{Na}_{2} \mathrm{Al}_{2} \mathrm{O}_{4}\right]$, polyaluminium chloride (PAC) $\left[\mathrm{Al}_{13}(\mathrm{OH})_{20}\left(\mathrm{SO}_{4}\right)_{2} \mathrm{Cl}_{15}\right]$, ferric sulfate $\left[\mathrm{Fe}_{2}\left(\mathrm{SO}_{4}\right)_{3}\right]$, ferric chloride $\left[\mathrm{FeCl}_{3} 6 \mathrm{H}_{2} \mathrm{O}\right]$, ferrous sulfate $\left[\mathrm{FeSO}_{4} \cdot 7 \mathrm{H}_{2} \mathrm{O}\right]$ and (hydrated) lime $\left[\mathrm{Ca}(\mathrm{OH})_{2}\right]$. In regard to lime, coagulation processes are of- 
ten combined with lime-soda softening, where upon addition of $\mathrm{Ca}(\mathrm{OH})_{2}$ and $\mathrm{Na}_{2} \mathrm{CO}_{3}$ (soda ash) the hardness of the water is reduced by partial precipitation of the little soluble $\mathrm{CaCO}_{3}$ and $\mathrm{Mg}(\mathrm{OH})_{2}$. Electrocoagulation is the electrochemical variant of the general coagulation technique. Here, coagulant material can be brought into treated water by a sacrificial anode, usually made of iron or aluminum. The electrocoagulation process distinguishes itself by its low cost, simple operation, and low sludge generation, which is usually less than that found in chemical coagulation/flocculation processes [142]. The anode can also partially oxidize some of the organic components of PW [143]. Electrode passivation can be an issue that limits the process [144], leading to increased power consumption. The addition of chloride ions [145], the use of alternating current [146] and of a polarity changing switch between the electrodes [144] [147] can mitigate this problem. Thus, electrocoagulation is viewed as an emerging technology for the purification of PW [148]. The influence of operating parameters in the EC driven separation of oil and water in $\mathrm{PW}$ such as current density, electrolysis time, $\mathrm{pH}$, supporting and electrolyte concentration has been studied [149] [150]. The electrocoagulation process can be combined with further treatment processes, such as reverse osmosis [151]. Electrocoagulation has been studied especially with PW from oil sands operations [152] and PW generally stemming from fracking processes [151]. Also here cost plays a role. A.Z. Rodriguez et al. [153] studied the use of PW gained from a salt water disposal facility in the Permian Basin, New Mexico, USA, as water for hydraulic fracturing. Here, chemical coagulation (CC) using ferric chloride and aluminum sulfate was compared as treatment process with electrocoagulation (EC) using aluminum electrodes. Aluminum sulfate was more effective as coagulant than ferric chloride. EC was run with a current density of $6.60 \mathrm{~mA} / \mathrm{cm}^{2}$ and resulted in $74 \%$ removal of suspended solids and $53 \%-78 \%$ removal of the total organic carbon (TOC). The energy requirement of EC was calculated at $0.36 \mathrm{kWh} / \mathrm{m}^{3}$ of water treated with the total operating cost of EC estimated at $\$ 0.44 / \mathrm{m}^{3}$ of treated water, 1.7 or 1.2 times higher than CC using alum or ferric chloride as the coagulant. After coagulation, the water was treated further through filtration through agricultural waste products (pecan shell, walnut shell and biochar) and/or through granular activated carbon.

\subsubsection{Advanced Oxidation Processes (AOPs) (as Tertiary Treatment)}

Chemical oxidation of PW oxygenates and hydroxylates organic and inorganic compounds, the contributors to the chemical oxygen demand (COD) of PW, ideally to $\mathrm{CO}_{2}$ and $\mathrm{H}_{2} \mathrm{O}$ in the case of organic contaminants and to more stable inorganic compounds. Typical oxidants that have been looked at are hydrogen peroxide $\left(\mathrm{H}_{2} \mathrm{O}_{2}\right)$, ozone $\left(\mathrm{O}_{3}\right)$, and metal hypochlorites $\left[\mathrm{M}(\mathrm{ClO})_{\mathrm{x}}\right]$. The oxidation process depends on $\mathrm{pH}$ of $\mathrm{PW}$, on the dose of oxidant and the contact time. In simple oxidation procedures, COD values of PW diminish only slowly. Thus, Shokrollahzadeh et al. [154] have studied the oxidative removal of hydrocarbons from gas-field produced water. Ozonation of $\mathrm{PW}$ for $1 \mathrm{~h}$ at $\mathrm{pH} 7.2$ resulted in 
$12 \%$ COD removal, hydrogen peroxide treatment at $\mathrm{pH} 7.2$ led to $15 \% \mathrm{COD}$ removal, and the employment of calcium hypochlorite $\left[\mathrm{Ca}(\mathrm{ClO})_{2}\right]$ at $300 \mathrm{mg} / \mathrm{L}$ PW resulted in a decrease of COD by $30 \%$. Nevertheless, advanced oxidation processes (AOPs) in PW treatment can be used as a polishing step, especially when an appreciable residual amount of organic material resides dissolved in PW, after it has gone through other treatment regimes. AOP processes can be photocatalytic [155], they can be Fenton-based processes and or a treatment of PW with ozone $\left(\mathrm{O}_{3}\right)$. Photocatalytic oxidation often uses $\mathrm{TiO}_{2}$ as photocatalyst. Hydroxyl and superoxide anion radicals are produced by the in situ generated electronhole pairs on $\mathrm{TiO}_{2}$ upon irradiation with light and play the part of the primary oxidants of the organic components in the PW, which lastly mineralize. Fenton reagent is the combination of iron (II) sulfate $\left(\mathrm{FeSO}_{4}\right)$ and hydrogen peroxide $\left(\mathrm{H}_{2} \mathrm{O}_{2}\right)$. Hydrogen peroxide oxidizes iron (II) to iron (III). At the same time hydroxyl radicals are produced. Iron (III) then reverts back to iron (II) upon reacting with another molecule of hydrogen peroxide. In this case, a hydroperoxy radical is formed. In all, iron acts as a catalyst to disproportionate two molecules of hydrogen peroxide to one molecule of hydroxyl radical and one molecule of hydroperoxy radical. Both free radicals oxidize carbon containing compounds, with the hydroxyl radical being less selective. The photo-Fenton reaction uses ferrous salts, hydrogen peroxide and UV irradiation. Photo-Fenton oxidations of PW have been run with solar irradiation, also [156]. Ozonation is used in wastewater treatment in general as a polishing step [157]. This includes the ozonation of drinking water, where one of the main purposes is the destruction of harmful protozoa. The upside of ozonation is that in the absence of bromides there are few if any by-products in the process. Ozonation, however, is not cheap. Often, ozone is combined with hydrogen peroxide, catalysts and/or UV irradiation in the actual treatment process. S. Jiménez et al. [158] have looked at the effectiveness of different AOP regimes in reducing the TOC in synthetic PWs, where toluene, xylene, naphthalene, phenol, acetic acid and malonic acid had been added to a seawater matrix. The authors found that a combination of ozone and hydrogen peroxide gave the best result in reducing TOC, with the worst results coming from the photocatalytic reactions used. Acetic acid was found to be one of the most recalcitrant compounds of PW [158].

\section{1) New AOP methodologies for the treatment of produced water}

A number of new laboratory methods have been tried to rid PW of PAHs under oxidative conditions. T. Haneef oxidized PAHs with potassium ferrate $\left(\mathrm{K}_{2} \mathrm{FeO}_{4}\right)$ in PW samples that were collected from an oil and gas exploration site in the South East Asia region [159]. The samples were loaded with a total PAH concentration of $1.25 \mathrm{mg} / \mathrm{L}$. The study showed that $89.7 \%$ of the PAHs could be eliminated under the optimal conditions, i.e., with a ferrate (VI) concentration of $19.35 \mathrm{mg} / \mathrm{L}$, at $\mathrm{pH} 7.1$, and with a contact time of $68.3 \mathrm{~min}$.

\subsection{Biological Treatment}

The biological treatment of PW in oil and gas production mimics the biological 
treatment of wastewater and includes conventional activated sludge processes, fixed-film reactors, membrane bioreactors and constructed wetlands. Although biological treatment of PW is seen as a very cost-effective method to reduce the organic content in $\mathrm{PW}$, biological treatment of $\mathrm{PW}$ from oil and gas production is not very common [160].

\subsubsection{Microbial Treatment (as Secondary and Tertiary Treatments)}

The microbial treatment of $\mathrm{PW}$ from oilfields has been reviewed previously [161]. For microbial treatment of produced water in general, one can distinguish between the conventional activated sludge processes (CASPs), which are extensively used in municipal wastewater treatment plants, where microorganisms are free to move in the water in self-made bioflocs, that are held together by polysaccharides and polyesters derived from the organisms themselves, and biological aerated filters (BAFs), where the microorganisms are attached to a solid support [162]. CASPs are usually less expensive to run, while BAF operations can work with a wider range of bacterial organisms which show more resistance towards the toxicity of the PW's contaminants. CASPs systems would normally need a settling tank to separate off the sludge. Work on the use of CASPs in PW from oil and gas fields is still limited [154] [163] [164] [165] [166]. As seen above, PW can have a wide range of salinity values. High salinity can have starkly detrimental effects on the bioremediation of PW because of bacterial-membrane disruptions, which can result in a decrease in biomass-respiration rates or settling issues. Two possibilities present themselves here, either acclimatize the biomass used in the aeration tank slowly to an increasing salinity or to work with halophilic organisms [167]. BTEX included in PW can be biodegraded under aerobic conditions [168] [169]. A number of Pseudomonas species can utilize benzene as sole carbon and energy source. Usually, oxygen is incorporated into the aromatic ring system through the action of mono-oxygenases and dioxygenases, leading to mono-hydroxylated and dihydroxylated aromatic compounds as the initial products, respectively. Other pathways in the aerobic biodegradation of BTEX have been described, also [170]. It must be noted that aerobic microbial treatment of PW in CASP can lead to the volatilization of BTEX [171] [172]. The volatilization needs to be taken into consideration because of the toxicity of BTEX, although it is not yet well studied [173]. Microbial treatment has been combined with oxidative pre-treatments. For this, it is of importance to tailor the oxidant to the microorganism used for the bioremediation. A typical oxidant that has been used is ozone.

\subsubsection{Membrane Bioreactor (MBR)}

In a membrane bioreactor (MBR), a suspended aerated sludge tank can also be combined with a membrane separation system rather than with a settling tank or clarifier. The water funneling through the outlet of the sludge tank is subjected to micro- or ultra-filtration, where either ceramic or polymeric membranes are used, with ceramic membranes, while more expensive, being chemically more 
resistant. The membrane can also be immersed in the aeration tank itself. MBRs have been used to treat petroleum wastewater [174], incl. PW from oil and gas production. Scholz and Fuchs [175] have shown that treatment of PW with MBR can lead to a better reduction in organic matter than treatment with classical activated sludge processes (ASP) [MBR: 97\% chemical oxygen demand (COD) removal efficiency and $99 \%$ oil removal efficiency vs. ASP: $82 \%$ COD and oil removal efficiencies]. However, studies with PW from a Qatari gas field have shown lower MBR removal efficiencies, attributed in the study to a significant fraction (approximately 40\%) of highly recalcitrant organic compounds, presumed to be nitrogen-containing field chemicals [176]. Often, significant problems of fouling of the membranes still need to be overcome. The fouling of membranes leads to additional costs incurred by frequent cleaning operations [177] [178]. Nevertheless, hypersaline PW can also be treated with MBRs [179].

\section{Typical Published and Studied Treatment Trains}

M. Ebrahimi et al. [180] studied the treatment of tank dewatering PW from German BP AG, Oil Refinery, Emsland, Lingen, using ceramic MF, UF and NF crossflow filtration in succession. UF filtration [UF- $\left(\mathrm{Al}_{2} \mathrm{O}_{3} / \mathrm{TiO}_{2}\right)-0.05 \mu \mathrm{m}$ ] of a PW feed with 565 ppm oil content led to $99 \%$ oil removal. The authors noted that MF was a suitable pretreatment for subsequent NF and UF. A TOC removal of $14 \%$ for a TOC feed concentration of $582 \mathrm{ppm}$ was less successful [180]. A follow-up study revealed that MF as pre-treatment led to $93 \%$ oil removal from oily PW, while MF in combination with NF and UF made an oil removal of 99.5\% possible [181]. These results are similar to those found by Mueller et al. [98] in the treatment of oily water from the Hueneme field in California, USA, where cross-filtration on two ceramic membranes (of 0.2 and $0.8 \mu \mathrm{m}$ pore sizes) led to $98 \%$ and $99 \%$ oil removal, respectively. Zhong et al. [182] described a ceramic membrane filtration $\left(0.2 \mu \mathrm{m} \mathrm{ZrO}_{2}\right)$ combined with a flocculation using 3530S, a derivative of polyacrylamide, as pre-treatment, a combination which was suitable for the final effluent the reach the discharge standard. Zhang et al. developed a train for the effective treatment of shale oil and gas PW derived from the Wattenberg field in NE Colorado, USA, which consisted of a precipitative softening (PSO) and a walnut shell filtration (WSF) followed by membrane distillation (MD) [183]. The boron and total BTEX concentrations in the MD distillate met the regulatory requirements for irrigation and typical discharge limits, respectively. Qiao et al. [184] developed a hybrid membrane pilot-scale plant to treat PW from an oilfield in Daqing, China. After the addition of PAC (polyaluminium chloride) and PAM (polyacrylamide) as demulsifying and coagulant agents, respectively, the PW is moved to an aeration tank, where most of the free oil is removed and sulfides are oxidized. Subsequently, it is subjected to air flotation to remove the remaining fine oil droplets. Then, the water is filtered over sand. Finally, it is subjected to UF through a PVC membrane [184]. The treated water met the required standard for discharging or injection water. With 
synthetic PW, Piemonte et al. [112] have studied the combination of a VSEP membrane system (see above) and reverse osmosis. As primary treatment an API oil separator was used, before coagulant was added to the PW, which was subsequently subjected to a dissolved gas flotation. After addition of polyelectrolytes, metals were separated off in a settling tank. Afterwards, the water was passed through a sand filter. Then, the water was sent to VESP ${ }^{\varpi}$ membrane nanofiltration system, which was able to completely reduce the TSS content of PW, while BOD5, COD, and TOC contents were reduced up to $90 \%$. However, the VESP $^{\circledR}$ membrane system was not able to reduce TDS reliably. RO units were used downstream, where the VESP ${ }^{\circledR}$ membrane permeate either passed through one or through two RO units. Here the TDS was reduced from $35,500 \mathrm{mg} / \mathrm{L}$ to $160 \mathrm{mg} / \mathrm{L}$ with one RO unit and from 160,670 mg/L to $160 \mathrm{mg} / \mathrm{L}$ with two RO units [112]. The unit costs for the wastewater train were calculated at $0.6 € / \mathrm{m}^{3}$ with one $\mathrm{RO}$ unit and at $5.0 € / \mathrm{m}^{3}$ with two RO units [112]. A process water treatment train developed by Qatargas [185] for its LNG facilities in Ras Laffan Industrial City, Qatar, includes a deoiler, a $\mathrm{H}_{2} \mathrm{~S}$ removal unit, a walnut shell filtration unit (WSF) and a membrane bioreactor (MBR). The effluent is used for limited irrigation. Alternatively, the effluent is treated with a granular activated carbon unit and then subjected to RO. The obtained permeate is used as boiler feed. The RO concentrate is mixed with produced water (PW) and injected into a disposal well [185] [186].

In more recent times, integrated membrane based systems have been developed such as combining electrodialysis, nanofiltration and membrane distillation (ED-NF-MD) for a highly efficient treatment of oilfield produced water [187]. Thus, Zhao et al. created a ED-NF-MD system that could concentrate produced water to high concentrations up to $373,000 \mathrm{mg}$ salt/L with a water recovery as high as $99.8 \%$ without the addition of chemicals such as soda or anti-scalants.

\section{Water Management and Brine Disposal Methods in the Middle East}

In the past, PW management was not a serious matter in the Middle East. Therefore, for some time, no large investments were made in new methodologies for the treatment of PW. The traditional PW disposal methods were mostly disposal pits, which are divided into two categories, sealed and unsealed (seepage) pits [188]. For the sealed evaporation pits, a protective layer made out of asphalt or lined plastic prevents the disposed fluid from filtering through and contaminating nearby free water aquifers [189]. These PW disposal pits were visible around the oilfields as they are above the surface. There are two other disposal methods that are underground, where the PW is injected into the subsurface through effluent disposal/injection wells, partially to aid enhanced oil recovery (EOR). Enhanced oil recovery methods reuse the PW to create greater pressure in the producing reservoir by reinjecting the $\mathrm{PW}$ back into the production zone to 
drive more quantities of produced fluid to the production wells to be lifted or extracted to the surface, unlike the effluent disposal wells, where the PW is treated as a waste and disposed of in the subsurface without being reused [18]. Nevertheless, for some oil fields such as in Abu Dhabi, there still is not enough injection water available so that seawater nanofiltration plants on the Arabian Gulf provide the water that will be transported by pipelines to the oilfields inland.

As in many areas of the world, environmental laws on the Arabian Peninsula became successively stricter. Thus, the Kuwaiti Environmental Law No. 12 of 2017 [190] states in article 17, concerning evaporation pits:

The oil and petroleum companies are to comply with the following regulations in the process of disposing of polluted and produced water in the oil fields:

1) Terminate the current evaporation pits and provide KEPA (Kuwait Environmental Public Authority) with the companies plan to remove such pits and rehabilitate them according to a set timeline.

2) Initiate the rehabilitation program by preparing an environmental impact assessment of the current situation including the treatment solutions and the time required within the operational scope of each company in the oil sector.

3) Prohibit the constructing of new evaporation pits for newly developed oil wells, and comply with the selection of the most efficient processes by installing treatment units and recycling the produced water on site, and dispose of it in the best manner according to the standards and specifications to use it after treatment along with an environmental impact assessment to predict the environmental gains of treating the produced water and efficiently disposing of it.

4) The oil and petroleum companies are to comply with the environmental and engineering standards set by the Environmental Law No. 2 of 2017 and its inclusive specifications concerning the oil and gas sector (KEPA).

The factors considered by the decision makers in Kuwait to comply with the above regulations were

1) Cost: The total cost includes labor, machinery, and any required material to be used in the disposal process. The total cost of each proposed method includes the whole life cycle of the system such as the initial investment capital, operational cost, maintenance cost, and abandonment cost [18].

2) Pollution: The environmental effects were considered of each disposal system according to international standards. The effects of each system on health and safety and the possibility of polluting ground and surface water, the atmosphere, and green and domestic areas had to be taken into consideration, and again the effects had to be within the specified environmental limits of the country [18].

3) Efficiency: The efficiency can be measured by being taken into account operability, maintainability, accessibility, supportability, and life span of the treatment and disposal system [18].

AlAnezi et al. [191] commented on PW management options in Kuwait and 
deemed that PW injection is the most expensive but also the most efficient method and the best for meeting environmental requirements. However, they also mentioned that because of stricter environmental regulations, local water shortages, and bans on disposal via deep well injection, in the future PW will need to be treated and eventually recycled and reused. However, Kuwaiti PW has very high salinity (TDS $\sim 200.000 \mathrm{mg} / \mathrm{L}$ ) with high sodium, potassium, calcium and magnesium contents [188] and a direct treatment by membrane processes is difficult to achieve [191]. Here, thermal treatment methods, although more costly, may be an option. Momentarily, $75 \%$ of the Kuwaiti domestic wastewater is treated to RO quality, of which $58 \%$ is reused. Only $19 \%$ of the water consumed in the agricultural sector is recycled water [192], and there is room for improvement.

Also, in Qatar environmental regulations led to new commitments of Qatar Petroleum and other producers towards the Ministry of the Environment, which included cutting wastewater injection volumes by $50 \%$ in the North Field [186].

Often, when large amounts of PW in arid regions are involved, the usage of such water for irrigation often presents itself then, when PW can be adequately treated. Thus, in general brackish water desalination is becoming an important source for water, in particular in areas that are remote from the sea. This is backed by the fact that $23 \%$ of the installed world desalination capacity comes from deep and shallow brackish water [193]. Since most of the hydrocarbon extraction operations take place onshore in the Arabian Peninsula and particularly in the Gulf Cooperation Council states of Kuwait, Saudi Arabia and the United Arab Emirates, it is becoming increasingly important to utilize the PW that accounts for the majority of the produced liquid on site, which is of a desert nature. The importance of the maximum utilization of the extracted resources is the subject of the least opposition. The technologies implemented and the implications are the usual questionable points. Early desalination methods are the multistage flash distillation (MSF) and the multiple effect distillation (MED). Both methods are energy intensive and therefore costly, however, they allow for installations with large throughput that have appreciable lifetimes often of over 20 years. Multi-effect distillation can be combined with ultrafiltration and with reverse osmosis [194]. In general, over time, membrane processes such as ultrafiltration and reverse osmosis have become more dominant [186]. Thus, the treatment of produced water streams in two advanced wastewater recycle and reduction (WRR) plants for LNG trains at Ras Laffan Industrial City in Qatar include apart from a conventional deoiler and degasser, as well as walnut shell and carbon filtration units, $\mathrm{MBR}$ and $\mathrm{RO}$ units as advanced treatment regimes [185] [186].

The most significant challenge, as desalination is applied in increasingly larger scale and varied locations, is the issue of concentrate disposal [193]. Studies indicate that it can be in the order of $15 \%$ of the costs of desalination in the case of inland sites, This is the usual condition at many inland installations which are 
located more than $80 \mathrm{~km}$ from the sea coast where disposal of concentrate to the sea becomes economically prohibitive due to the unavoidable nor adjustable cost of transportation [193]. Difficulties in disposing of the concentrate have been named as one of the reasons of not installing inland desalination plants at many locations in the United States, where desalinated water would be urgently needed [125].

Often, brine concentrators are used to reduce the volume of the brine stream. Many of the brine concentrators are based on mechanical vapor compression (MVC) [195]. Here, the brine feed is preheated in heat exchangers utilizing the heat content of the distillate product water coming out of the MVC unit. The brine feed then is mixed with recirculating brine slurry stemming from the previous cycle. The mixture is fed to the top of the concentrator and flows in a thin film along a bundle of heat transfer tubes. The water vapor that is produced collects in the vapor compressor which brings the superheated compressed vapor to the external surface of the heat transfer tubes, where the vapor condenses heating in return the brine feed (see above). MVC are energy intensive, with a consumption of $20-25 \mathrm{kWh} / \mathrm{m}^{3}$ feedwater [125], where higher values up to 39 $\mathrm{kWh} / \mathrm{m}^{3}$ feedwater have been reported, also [125] [196]. The concentrated brines are sent to either brine crystallizers or to evaporation ponds. While brine crystallizers again are quite energy consuming $\left(52-66 \mathrm{kWh} / \mathrm{m}^{3}\right.$ feedwater), evaporation ponds can present an environmental hazard [125]. The water distillate from the brine concentrator and from the brine crystallizer is clean water which can be re-used, while the brine residue from the brine crystallizer either goes to the landfill or is processed further to extract salts of commercial interest from it such as lithium salts [197] [198] by precipitation as lithium phosphate or lithium carbonate.

\section{Potential Uses of Non-Reinjected Produced Water}

For some time, it has been investigated whether PW can be used for irrigation of non-food crops [199] [200] [201] and of landscape greenery [202]. In fact, California [13], Montana, and Wyoming irrigate crops with PW from conventional oil and gas sources. Nevertheless, a new study [203] has found that addition of PW to irrigation water can affect the crop yield of plants such as spring wheat ( Triticum aestivum). Comparison with the effect of treatment with $\mathrm{NaCl}_{50}$ seems to indicate that constituents in PW other than salt influence the crop health. With wheat leaves inoculated with bacterial and fungal pathogens it has been shown that use of PW in irrigation reduces PR-gene expression by reallocating metabolic resources to fight abiotic stress than to fight pathogens [199]. The residual TOC of PW seems to affect the health of the plants in equal measure and it has been suggested to keep the TOC concentration to less than $5 \mathrm{mg} / \mathrm{L}$ [204]. At any rate, it seems that for a prolonged use of $\mathrm{PW}$ for irrigation purposes it should be pre-treated and diluted with clean water [205], where dilution is the more important factor. Thus, $90 \%$ dilution of produced water with clean water 
has a greater effect than any water treatment investigated at 50\% dilution. Irrigation of sunflower (Helianthus annuus) and wheat (Triticum aestivum) with high proportions (50\%) of raw or treated PW led to stunted growth of the plants, with reduced height and leaf area [206]. The sunflower seed saw 100\% yield loss [206]. Also, in Oman, Yemen and Qatar irrigation experiments have been carried out with PW. Thus, PW from an Omani conventional oilfield, treated by air flotation and subsequent filtration over anthracite and activated carbon was used to irrigate alfalfa, barley and Rhodes grass. In contrast to alfalfa, barley and Rhodes grass were little affected by the irrigation with PW. However, the irrigation with treated PW led to an increase in soil salinity and sodicity, even within a relatively short time [207]. The fresh weight of alfalfa grown on PW from a conventional gas field was significantly reduced as compared to alfalfa grown on tap water under the same conditions [208]. All the above also limits the use of phytoremediation to purify PW [209], although the use of both constructed wetlands and rhyzofiltration for PW purification is not yet off the table [210]. A treatment of produced water from oil production wells using a hybrid reverse osmosis-constructed wetland treatment system was studied by Murray-Gulde et al. [211]. The researchers found that the treated water was suitable for irrigation or discharged to surface waters, except that additional treatment was necessary to decrease the boron levels in $\mathrm{PW}$, if the water was to be used for irrigation. A pilot subsurface flow constructed wetland $(\mathrm{CW})$ was constructed in the Liaohe Delta, China to treat heavy oil-produced water [212]. In this regard, the NIMR water treatment project in Oman [213] [214] must be mentioned, which is used to manage $115.000 \mathrm{~m}^{3} /$ day PW of the NIMR oilfield with 360 ha of surface flow constructed wetlands and 500 ha of downstream evaporation ponds. Before the PW reaches the constructed wetlands the majority of the oil is separated from the water by a series of skimmers and passive hydrocyclone oil separators. Then, the PW is distributed via a long inlet buffer pond over the wetlands and flows into evaporation ponds. PW at the inlet has a TDS of about $7.000 \mathrm{ppm}$ and contains about $30 \mathrm{ppm}$ hydrocarbons, with the effluent carrying $<0.5 \mathrm{mg} \mathrm{OiW} / \mathrm{L}$, the remainder of the hydrocarbons having been biologically degraded [213]. The wetland was initially built with common reeds (Phragmites australis), but a further 4 local plant species (Typha domingensis, Schoenoplectus littoralis, Juncus rigidus and Cyperus spp. were introduced at a later time. An earlier project with PW from a conventional oilfield in Yemen treated in a constructed wetland (reed bed) showed the possibility to grow cotton with the treated PW [215]. Meanwhile, also other countries in the Middle East such as Bahrain are contemplating to create artificial wetlands to treat produced water.

It is in the interest of the countries on the Arabian Peninsula to utilize PW from oil- and gas fields for non-reinjection purposes such as for irrigation. For this, new water management frameworks are being devised in Qatar [66] [216] [217]. In addition, there is the GCC Unified Water Strategy (2016-2035), which has as its goal a $90 \%$ reuse of treated wastewater in general by 2035 [218]. As the 
Arabian Gulf has the world's highest density of desalination plants with potential associated environmental consequences for the Arabian Gulf [219] and Red Sea [220] in view of salinity and temperature increase, it is opportune to augment the water gained by seawater desalination with treated PW from oil and gas operations.

\section{Conclusion}

With the predicted increase of oil and gas extraction, at least over the next two decades, and with the maturation of a larger number of oil fields, it is expected that the volume of PW from oil and gas field operations will increase over the next years. The passing of new, more stringent environmental laws will restrict the disposal and use of PW even more than today. At the same time, resources of clean water are diminishing worldwide at an alarming rate. In arid regions, where many of the oil and gas fields are located, it would be opportune to use treated PW for purposes normally reserved for clean or treated municipal wastewater such as for irrigation. The requirement would be a cost-effective treatment of PW that would give water of sufficient quality. With the development of new PW treatment regimes, that goal can be within reach,

\section{Conflicts of Interest}

The authors declare no conflicts of interest regarding the publication of this paper.

\section{References}

[1] Stephenson, M.T. (1992) Components of Produced Water: A Compilation of Industry Studies. Journal of Petroleum Technology, 44, 548-603.

https://doi.org/10.2118/23313-PA

[2] Krause, P.R. (1995) Spatial and Temporal Variability in Receiving Water Toxicity near an Oil Effluent Discharge Site. Archives of Environmental Contamination and Toxicology, 29, 523-529. https://doi.org/10.1007/BF00208383

[3] McCormack, P., Jones, P., Hetheridge, M.J. and Rowland, S.J. (2001) Analysis of Oilfield Produced Water and Production Chemicals by Electrospray Ionization Multistage Mass Spectrometry (ESI-MSn). Water Research, 35, 3567-3578. https://doi.org/10.1016/S0043-1354(01)00070-7

[4] Clark, C.E. and Veil, J.A. (2009) Produced Water Volumes and Management Practices in the United States, Argonne National Lab. ANL, Argonne, IL. https://doi.org/10.2172/1007397

[5] Haneef, T., Mustafa, M.R.U., Farhan Yasin, H.M., Farooq, S. and Hasnain Isa, M. (2020) Study of Ferrate(VI) Oxidation for COD Removal from Wastewater. IOP Conference Series. Earth and Environmental Science, 442, Article ID: 012007. https://doi.org/10.1088/1755-1315/442/1/012007

[6] Haneef, T., Mustafa, M.R.U., Rasool, K., Ho, Y.C. and Mohamed Kutty, S.R. (2020) Removal of Polycyclic Aromatic Hydrocarbons in a Heterogeneous Fenton Like Oxidation System Using Nanoscale Zero-Valent Iron as a Catalyst. Water, 12, Article 2430. https://doi.org/10.3390/w12092430 
[7] Al-Ghouti, M., Al-Kaabi, M., Ashfaq, M.Y. and Da'na, D.A. (2019) Produced Water Characteristics, Treatment and Reuse. Journal of Water Process Engineering, 28, 222-239. https://doi.org/10.1016/j.jwpe.2019.02.001

[8] McCabe, P. (2012) Oil and Natural Gas: Global Resources. In: Malhotra, R., Ed., Fossil Energy, Springer, New York, 7-23.

https://doi.org/10.1007/978-1-4614-5722-0_2

[9] IHS-Market Analysis (2020) Produced Water from Onshore US Oil and Gas Activities to Decline to Nearly 20 Billion Barrels Annually; Reach \$28 Billion in Value by 2022, IHS Markit Says.

https://news.ihsmarkit.com/prviewer/release_only/slug/2020-04-02-produced-water -from-onshore-us-oil-and-gas-activities-to-decline-to-nearly-20-billion-barrels-ann ual-

ly-reach-28-billion-in-value-by-2022-ihs-markit-says\#: :text=HOUSTON\%20(Apri $1 \% 202 \% 2$ C\%202020),in\%20critical\%20information\%2C\%20analytics\%20and

[10] ERCB (2012) Alberta's Energy Reserves 2011 and Supply/Demand Outlook 20122021. Energy Resources Conservation Board ST98-2012, Calgary, AB.

[11] Alberta Chamber of Resources (2004) Oil Sands Technology Roadmap: Unlocking the Potential. Edmonton, AB.

[12] Transparency Market Research Editorial Team (2021) Produced Water Treatment Market to Reach Valuation of \$ 87.4 Billion Dollars by 2031. Oil \& Gas Middle East. https://www.oilandgasmiddleeast.com/exploration-production/drillling-production 138198-produced-water-treatment-market-to-reach-valuation-of-874-billion-by-20 $\underline{31}$

[13] Gray, M. (2020) Reuse of Produced Water in the Oil and Gas Industry. The SPE International Conference and Exhibition on Health, Safety, Environment, and Sustainability, Virtual, 27-30 July 2020, SPE-199498-MS. https://doi.org/10.2118/199498-MS

[14] Hedar, Y. and Yono, B. (2018) Pollution Impact and Alternative Treatment for Produced Water. E3S Web of Conferences, 31, Article ID: 03004. https://doi.org/10.1051/e3sconf/20183103004

[15] Fakhru'l-Razi, A., Pendashteh, A., Abdullah, L.C., Biak, D.R.A., Madaeni, S.S. and Abidin, Z.Z. (2009) Review of Technologies for Oil and Gas Produced Water Treatment. Journal of Hazardous Materials, 170, 530-551. https://doi.org/10.1016/j.jhazmat.2009.05.044

[16] Guerra, K., Dahm, K. and Dundorf, S. (2011) Oil and Gas Produced Water Management and Beneficial Use in the Western United States. Bureau of Reclamation DWPR, Report No. 157.

[17] Liden, T.M. (2018) Characterization and Remediation of Wastewater from Unconventional Oil and Gas Development. PhD Thesis, The University of Texas at Arlington, Arlington, TX.

[18] Al-Hubail, J. and El-Dash, K. (2006) Managing Disposal of Water Produced with Petroleum in Kuwait. Journal of Environmental Management, 79, 43-50. https://doi.org/10.1016/j.jenvman.2005.05.012

[19] Hanson, B.R. and Davies, S.H. (1994) Review of Potential Technologies for the Removal of Dissolved Components from Produced Water. Chemical Engineering Research and Design, 72, 176-188.

[20] He, Y. and Jiang, Z.W. (2008) Treating Oilfield Wastewater: Technology Review. Filtration \& Separation, 45, 14-16. https://doi.org/10.1016/S0015-1882(08)70174-5 
[21] Olajire, A.A. (2020) Recent Advanced on the Treatment Technology of Oil and Gas Produced Water for Sustainable Energy Industry-Mechanistic Aspects and Process Chemistry Perspectives. Chemical Engineering Journal Advances, 4, Article ID: 100049. https://doi.org/10.1016/j.ceja.2020.100049

[22] Jiménez, S., Mico, M.M., Arnaldos, M., Medina, F. and Contreras, S. (2018) State of the Art of Produced Water Treatment. Chemosphere, 192, 186-208.

https://doi.org/10.1016/j.chemosphere.2017.10.139

[23] Igunnu, E.T. and Chen, G.Z. (2014) Produced Water Treatment Technologies. International Journal of Low-Carbon Technologies, 9, 157-177. https://doi.org/10.1093/ijlct/cts049

[24] Neff, J., Lee, K. and DeBlois, E. (2011) Chapter 1. Produced Water: Overview of Composition, Fates, and Effects. In: Lee, K. and Neff, J., Eds., Produced Water, Springer, New York, 3-54. https://doi.org/10.1007/978-1-4614-0046-2_1

[25] Nonato, T.C.M., Alves, A.A.A., Sens, M.L. and Dalsasso, R.L. (2018) Produced Water from Oil-A Review of the Main Treatment Technologies. Journal of Environmental Chemistry and Toxicology, 2, 23-27.

[26] Danforth, C., Chiu, W.A., Rusyn, I., Schultz, K., Bolden, A., Kwiatkowski, C. and Craft, E. (2020) An Integrative Method for Identification and Prioritization of Constituents of Concern in Produced Water from Onshore Oil and Gas Extraction. Environmental International, 134, Article ID: 105280. https://doi.org/10.1016/j.envint.2019.105280

[27] Henderson, S.B., Grigson, S.J.W., Johnson, P. and Roddie, B.D. (1999) Potential Impact of Production Chemicals on the Toxicity of Produced Water Discharges from North Sea Oil Platforms. Marine Pollution Bulletin, 38, 1141-1151. https://doi.org/10.1016/S0025-326X(99)00144-7

[28] Bird, K.J. and Houseknecht, D.W. (2002) U.S. Geological Survey 2002 Petroleum Resource Assessment of the National Petroleum Reserve in Alaska (NPRA). FS 045-02. https://pubs.usgs.gov/fs/2002/fs045-02/

[29] USEPA (2000) Profile of the Oil and Gas Extraction Industry. EPA Office of Compliance Sector Notebook Project EPA/310-R-99-006.

[30] Tibbetts, P.J.C., Buchanan, L.T., Gawel, L.J. and Large, R. (1992) A Comprehensive Determination of Produced Water Composition. In: Ray, J.P. and Engelhardt, R.R., Eds., Produced Water, Plenum Publishing Corp., New York, 97-112. https://doi.org/10.1007/978-1-4615-2902-6_9

[31] Cluff, M.A., Hartsock, A., MacRae, J.D., Carter, K. and Mouser, P.J. (2014) Temporal Changes in Microbial Ecology and Geochemistry in Produced Water from Hydraulically Fractured Marcellus Shale Gas Wells. Environmental Science \& Technology, 48, 6508-6517. https://doi.org/10.1021/es501173p

[32] Warner, N.R., Darrah, T.H., Jackson, R.B., Millot, R., Kloppmann, W. and Vengosh, A. (2014) New Tracers Identify Hydraulic Facturing Fluids and Accidental Releases from Oil and Gas Operations. Environmental Science \& Technology, 48, 12552-12560. https://doi.org/10.1021/es5032135

[33] Gregory, K.B., Vidic, R.D. and Dzombak, D.A. (2011) Water Management Challenges Associated with the Production of Shale Gas by Hydraulic Fracturing. Elements, 7, 181-186. https://doi.org/10.2113/gselements.7.3.181

[34] Yeung, C., Law, B.A., Milligan, T.G., Lee, K., Whyte, L.G. and Greer, C.W. (2011) Analysis of Bacterial Diversity and Metals in Produced Water, Seawater and Sediments from an Offshore Oil and Gas Production Platform. Marine Pollution Bulletin, 62, 2095-2105. https://doi.org/10.1016/j.marpolbul.2011.07.018 
[35] Utvik, T.I.R. (1999) Chemical Characterization of Produced Water from Four Offshore Oil Production Platforms in the North Sea. Chemosphere, 39, 2593-2606. https://doi.org/10.1016/S0045-6535(99)00171-X

[36] Alley, B., Beebe, A., Rodgers Jr., J. and Castle, J.W. (2011) Chemical and Physical Characterization of Produced Waters from Conventional and Unconventional Fossil Fuel Resources. Chemosphere, 85, 74-82. https://doi.org/10.1016/j.chemosphere.2011.05.043

[37] Khan, N.A., Engle, M., Dungan, B., Holguin, F.O., Xu, P. and Carroll, K.C. (2016) Volatile-Organic Molecular Characterization of Shale-Oil Produced Water from the Permian Basin. Chemosphere, 148, 126-136. https://doi.org/10.1016/j.chemosphere.2015.12.116

[38] Fillo, J.P. and Evans, J.M. (1990) Characterization and Management of Produced Waters from Underground Natural Gas Storage Reservoirs. American Gas Association Section Proceedings, Calgary, 6-9 June 1990, 448-459.

[39] Ekins, P., Vanner, R. and Firebrace, J. (2006) Zero Emissions of Oil in Water from Offshore Oil and Gas Installations: Economic and Environmental Implications. Journal of Cleaner Production, 15, 1302-1315. https://doi.org/10.1016/j.jclepro.2006.07.014

[40] USGS (2002) Produced Waters Database. U.S. Department of the Interior. https://www.usbr.gov/research/dwpr/reportpdfs/report157.pdf

[41] Nasiri, M. and Jafari, I. (2017) Produced Water from Oil-Gas Plants: A Short Review on Challenges and Opportunities. Periodica Polytechnica Chemical Engineering, 61, 73-81. https://doi.org/10.3311/PPch.8786

[42] Adewumi, U.P.W. (2002) USGS Produced Water Database, US Department of the Interior.

[43] Wandera, D., Wickramasinghe, S.R. and Husson, S.M. (2011) Modification and Characterization of Ultrafiltration Membranes for Treatment of Produced Water. Journal of Membrane Science, 373, 178-188. https://doi.org/10.1016/j.memsci.2011.03.010

[44] Fillo, J.P., Koraido, S.M. and Evans, J.M. (1992) Sources, Characteristics, and Management of Produced Waters from Natural Gas Production and Storage Operations. In: Ray, J.P. and Engelhardt, F.R., Eds., Produced Water, Environmental Science Research, Vol. 46, Springer, Boston, MA, 151-161.

https://doi.org/10.1007/978-1-4615-2902-6_12

[45] Bhadja, P. and Kundu, R. (2012) Status of the Seawater Quality at Few Industrially Important Coasts of Guarajat (India) off Arabian Sea. Indian Journal of Geo-Marine Sciences, 41, 90-97. http://nopr.niscair.res.in/handle/123456789/13461

[46] Hardi, M., Siregar, Y.I., Anita, S. and Illza, M. (2019) Determination of Heavy Metals Concentration in Produced Water of Oil Field Exploration in Siak Regency. Journal of Physics: Conference Series, 1156, Article ID: 012009. https://doi.org/10.1088/1742-6596/1156/1/012009

[47] Ricceri, F., Giagnorio, M., Farinelli, G., Blandini, G., Minella, M., Vione, D. and Tiraferri, A. (2019) Desalination of Produced Water by Membrane Distillation: Effect of the Feed Components and of a Pre-Treatment by Fenton Oxidation. Scientific Reports, 9, Article No. 14964. https://doi.org/10.1038/s41598-019-51167-Z

[48] Johnson, B.M., Kanagy, L.E., Rodgers Jr., J.H. and Castle, J.W. (2008) Chemical, Physical, and Risk Characterization of Natural Gas Storage Produced Waters. Water, Air and Soil Pollution, 191, 33-54. https://doi.org/10.1007/s11270-007-9605-8 
[49] Shepherd, M.C., Shore, F.L., Mertens, S.M. and Gibson, J.S. (1992) Characterization of Produced Waters from Natural Gas Production and Storage Operations. In: Ray, J.P. and Engelhardt, F.R., Eds., Produced Water. Technologicall Environmental Issues and Solutions, Plenum Publishing Corp., New York, 163-173. https://doi.org/10.1007/978-1-4615-2902-6_13

[50] Ayers, R.C. and Parker, M. (2001) Produced Water Waste Management. Canadian Association of Petroleum Producers (CAPP), Calgary, Alberta.

[51] McIntosh, J.C., Walter, L.M. and Martini, A.M. (2002) Pleistocene Recharge to Midcontinent Basins: Effects on Salinity Structure and Microbial Gas Generation. Geochimica et Cosmochimica Acta, 66, 1681-1700. https://doi.org/10.1016/S0016-7037(01)00885-7

[52] McIntosh, J.C. and Walter, L.M. (2005) Volumetrically Significant Recharge of Pleistocene Glacial Meltwaters into Epicratonic Basins: Constraints Imposed by Solute Mass Balances. Chemical Geology, 222, 292-309.

https://doi.org/10.1016/j.chemgeo.2005.07.010

[53] Neff, J.M. (2002) Bioaccumulation in Marine Organisms. Effects of Contaminants from Oil Well Produced Water. Elsevier Science Publishers, Amsterdam, 452 p. https://doi.org/10.1016/B978-008043716-3/50002-6

[54] OLF, The Norwegian Oil Industry Association (1997) Database of Chemical Composition of Produced Water from Norwegian Oil and Gas Production Fields. Available at OLF, Stavanger, Norway.

[55] NOROG, Norsk Olje og gass (2018) Miljørapport. Technical Report.

[56] Nepstad, R., Hansen, B.H. and Skancke, J. (2021) North Sea Produced Water PAH Exposure and Uptake in Early Life Stages of Atlantic Cod. Marine Environmental Research, 163, Article ID: 105203. https://doi.org/10.1016/j.marenvres.2020.105203

[57] Lofthus, S., Almås, I.K., Evans, P., Pelz, O. and Brakstad, O.G. (2018) Biodegradation in Seawater of PAH and Alkylphenols from Produced Water of a North Sea Platform. Chemosphere, 206, 465-473.

https://doi.org/10.1016/j.chemosphere.2018.05.006

[58] Neff, J.M., Sauer, T.C. and Hart, A.D. (2001) Monitoring Polycyclic Aromatic Hydrocarbons (PAH) Bioavailability near Offshore Produced Water Discharges. In: American Society for Testing and Materials Special Technical Publication, Vol. 1403, ASTM International, West Conshohocken, 160-180.

[59] Soliman, Y.S., Al Ansari, E.M.S. and Wade, T.L. (2014) Concentration, Composition and Sources of PAHs in the Coastal Sediments of the Exclusive Economic Zone (EEZ) of Qatar, Arabian Gulf. Marine Pollution Bulletin, 85, 542-548. https://doi.org/10.1016/j.marpolbul.2014.04.027

[60] Beg, M.U., Saeed, T., Al-Muzaini, Beg, K.R. and Al-Bahloul, M. (2003) Distribution of Petroleum Hydrocarbon in Sediment from Coastal Area Receiving Effluents in Kuwait. Ecotoxicology and Environmental Safety, 54, 47-55. https://doi.org/10.1016/S0147-6513(02)00019-2

[61] Al-Mur, B.A. (2019) Assessing the Ecological Risks from Hydrocarbons in the Marine Coastal Sediments of Jeddah, Red Sea. Environmental Monitoring and Assessment, 191, Article No. 180. https://doi.org/10.1007/s10661-019-7262-1

[62] Liu, Y., Lu, H., Li, Y., Xu, H., Pan, Z., Dai, P., Wang, H. and Yang, Q. (2021) A Review of Treatment Technologies for Produced Water in Offshore Oil and Gas Fields. Science of the Total Environment, 775, Article ID: 145485.

https://doi.org/10.1016/j.scitotenv.2021.145485 
[63] Zheng, J., Chen, B., Thanyamanta, W., Hawboldt, K., Zhang, B. and Liu, B. (2016) Offshore Produced Water Management: A Review of Current Practice and Challenges in Harsh/Arctic Environments. Marine Pollution Bulletin, 104, 7-19. https://doi.org/10.1016/j.marpolbul.2016.01.004

[64] Sutton, P.M., Mishra, P.N. and Crawford, P.M. (1994) Combining Biological and Physical Processes for Complete Treatment of Oily Wastewaters. International Biodeterioriation and Biodegradation, 33, 3-21. https://doi.org/10.1016/0964-8305(94)90052-3

[65] Judd, S., Qiblawey, H., Al-Marri, M., Clarkin, C., Watson, S., Ahmed, A. and Bach, S. (2014) The Size and Performance of Offshore Produced Water Oil-Removal Technologies for Reinjection. Separation and Purification Technology, 134, 241-246. https://doi.org/10.1016/j.seppur.2014.07.037

[66] Dawood, H.D., Saleem, H., Alnuaimi, N.A. and Zaidi, S.J. (2021) Characterization and Treatment Technologies Applied for Produced Water in Qatar. Water, 13, Article 3573. https://doi.org/10.3390/w13243573

[67] Luo, X., Gong, H., Cao, J., Yin, H., Yan, Y. and He, L. (2019) Enhanced Separation of Water-in-Oil Emulsions Using Ultrasonic Standing Waves. Chemical Engineering Science, 203, 285-292. https://doi.org/10.1016/j.ces.2019.04.002

[68] Mhatre, S., Vivacqua, V., Ghadiri, M., Abdullah, A.M., Al-Marri, M.J., Hassanpour, A., Hewakandamby, B., Azzopardi, B. and Kermani, B. (2015) Electrostatic Phase Separation: A Review. Chemical Engineering Research and Design, 96, 177-195. https://doi.org/10.1016/j.cherd.2015.02.012

[69] Le, T.T., Ngo, S.I., Lim, Y.I., Park, C.K., Lee, B.D., Kim, B.G. and Lim, D.H. (2018) Three-Phase Eulerian Computational Fluid Dynamics of Air-Water-Oil Separator under Off-Shore Operation. Journal of Petroleum Science and Engineering, 171, 731-747. https://doi.org/10.1016/j.petrol.2018.08.001

[70] Liu, L., Zhao, L., Yang, X., Wang, Y., Xu, B. and Liang, B. (2019) Innovative Design and Study of an Oil-Water Coupling Separation Magnetic Hydrocyclone. Separation and Purification Technology, 213, 389-400. https://doi.org/10.1016/j.seppur.2018.12.051

[71] Gong, H., Yu, B., Dai, F., Peng, Y. and Shao, J. (2018) Simulation on Performance of a Demulsification and Dewatering Device with Coupling Double Fields: Swirl Centrifugal Field and High-Voltage Electric Field. Separation and Purification Technology, 207, 124-132. https://doi.org/10.1016/j.seppur.2018.06.049

[72] Farias, F.P.M., Souza, J., de Lima, W., de Macêdo, A., Neto, S.R.F. and Lima, A. (2011) Influence of Geometric Parameters of the Hydrocyclone and Sand Concentration on the Water/Sand/Heavy-Oil Separation Process: Modeling and Simulation. The International Journal of Multiphysics, 5, 187-202. https://doi.org/10.1260/1750-9548.5.3.187

[73] Ahan, J.A. (2014) Characterization of Produced Water from Two Offshore Oil Fields in Qatar; Environmental Engineering College of Engineering, Qatar University: Doha, Qatar.

https://qspace.qu.edu.qa/handle/10576/3287/restricted-resource?bitstreamId=0fb37 632-1e3b-4851-a058-80c438f15419

[74] Piccioli, M., Aanesen, S.V., Zhao, H., Dudek, M. and Øye, G. (2020) Gas Flotation of Petroleum Produced Water: A Review on Status, Fundamental Aspects, and Perspectives. Energy \& Fuels, 34, 15579-15592.

https://doi.org/10.1021/acs.energyfuels.0c03262

[75] Eftekhardadkhah, M., Aanesen, S.V., Rabe, K. and Øye, G. (2015) Oil Removal from 
Produced Water during Laboratory- and Pilot-Scale Gas Flotation: The Influence of Interfacial Adsorption and Induction Times. Energy Fuels, 29, 7734-7740. https://doi.org/10.1021/acs.energyfuels.5b02110

[76] Das, T. and Jäschke, J. (2019) Simplified First-Principles Model of a Compact Flotation Unit for Use in Optimization and Control. Industrial \& Engineering Chemical Research, 58, 1273-1285. https://doi.org/10.1021/acs.iecr.8b04018

[77] Spellman, F.R. (2003) Handbook of Water and Wastewater Treatment Plant Operations. CRC Press, New York. https://doi.org/10.1201/9780203489833

[78] Sueyoshi, M., Al-Maamari, R.S., Jibril, B., Tasaki, M., Okamura, K., Kuwagaki, H., Yahiro, H., Sagata, K. and Han, Y. (2012) Preparation and Characterization of Adsorbents for Treatment of Water Associated with Oil Production. Journal of Analytical and Applied Pyrolysis, 97, 80-87. https://doi.org/10.1016/j.jaap.2012.04.003

[79] Yousef, R., Qiblawey, H. and El-Naas, M.H. (2020) Adsorption as a Process for Produced Water Treatment: A Review. Processes, 8, Article 1657.

https://doi.org/10.3390/pr8121657

[80] Janks, J.S. and Cadena, F. (1992) Investigations into the Use of Modified Zeolites for Removing Benzenes, Toluene and Xylene from Saline Produced Water. In: Ray, J.P. and Engelhardt, F.R., Eds., Produced Water. Technologicall Environmental Issues and Solutions, Plenum Publishing Corp., New York, 473-488. https://doi.org/10.1007/978-1-4615-2902-6_37

[81] Zheng, Y., Liu, W., Wang, Q., Sun, Y., Li, G., Wu, T. and Li, Y. (2020) Study of STABand DDAB-Modified Sepiolite Structures and Their Adsorption Performance for Emulsified Oil in Produced Water. Colloids and Interface Science Communications, 34, Article ID: 100231. https://doi.org/10.1016/j.colcom.2019.100231

[82] Okiel, K., El-Sayed, M. and El-Kady, M.Y. (2011) Treatment of Oil-Water Emulsions by Adsorption onto Activated Carbon, Bentonite and Deposited Carbon. Egyptian Journal of Petroleum, 20, 9-15. https://doi.org/10.1016/j.ejpe.2011.06.002

[83] Emam, E. (2013) Modified Activated Carbon and Bentonite Used to Adsorb Petroleum Hydrocarbons Emulsified in Aqueous Solution. American Journal of Environmental Protection, 2, 161-169. https://doi.org/10.11648/j.ajep.20130206.17

[84] Ibrahim, T., Gulistan, A., Khamis, M., Ahmed, H. and Aidan, A. (2016) Produced Water Treatment Using Naturally Abundant Pomegranate Peel. Desalination and Water Treatment, 57, 6693-6701. https://doi.org/10.1080/19443994.2015.1010235

[85] El-Nafaty, U., Misau, I. and Abdulsalam, S. (2013) Biosorption and Kinetic Studies on Oil Removal from Produced Water Using Banana Peel. Civil and Environmental Research, 3, 125-136.

[86] Al Haddabi, M., Znad, H. and Ahmed, M. (2015) Removal of Dissolved Organic Carbon from Oily Produced Water by Adsorption onto Date Seeds: Equilibrium, Kinetic, and Thermodynamic Studies. Water, Air, \& Soil Pollution, 226, Article No. 172. https://doi.org/10.1007/s11270-015-2443-1

[87] Hosny, R., Fathy, M., Ramzi, M., Moghny, T.A., Desouky, S. and Shama, S. (2016) Treatment of the Oily Produced Water (OPW) Using Coagulant Mixtures. Egyptian Journal of Petroleum, 25, 391-396. https://doi.org/10.1016/j.ejpe.2015.09.006

[88] Srinivasan, A. and Viraraghavan, T. (2008) Removal of Oil by Walnut Shell Media. Bioresource Technology, 99, 8217-8220. https://doi.org/10.1016/j.biortech.2008.03.072

[89] Rawlins, C.H. (2012) Performance and Limitations of Cyclonic and Walnut Shell Filtration Technologies to Oil and Solids Removal from Produced Water. SPE Workshop Produced Water Handling, Terranea Resort, CA, 27-28 June 2012, 13 p. 
[90] De Caprariis, B., Filippis, P.D., Hernandez, A.D., Petrucci, E., Petrullo, A., Scarsella, M. and Turchi, M. (2017) Pyrolysis Wastewater Treatment by Adsorption on Biochars Produced by Poplar Biomass. Journal of Environmental Management, 197, 231-238. https://doi.org/10.1016/j.jenvman.2017.04.007

[91] Alzahrani, S. and Mohammad, A.W. (2014) Challenges and Trends in Membrane Technology Implementation for Produced Water Treatment: A Review. Journal of Water Process Engineering, 4, 107-133. https://doi.org/10.1016/j.jwpe.2014.09.007

[92] Munirasu, S., Haija, M.A and Banat, F. (2016) Use of Membrane Technology for Oil Field and Refinery Produced Water Treatment-A Review. Process Safety and Environmental Protection, 100, 183-202. https://doi.org/10.1016/j.psep.2016.01.010

[93] Zolghadr, E., Firouzjaei, M.D., Amouzandeh G., LeClair, P. and Elliott, M. (2021) The Role of Membrane-Based Technologies in Environmental Treatment and Reuse of Produced Water. Frontiers in Environmental Science, 9, Article 71. https://doi.org/10.3389/fenvs.2021.629767

[94] Çakmakçe, M., Kayaalp, N. and Koyunucu, I. (2008) Desalination of Produced Water from Oil Production Fields by Membrane Processes. Desalination, 222, 176-186. https://doi.org/10.1016/j.desal.2007.01.147

[95] Miller, D.J., Huang, X., Li, H., Kasemsat, S., Lee, A., Agnihotri, D., Hayes, T., Paul, D.R. and Freeman, B.D. (2013) Fouling-Resistant Membranes for the Treatment of Flowback Water from Hydraulic Shale Fracturing: A Pilot Study. Journal of Membrane Science, 437, 265-275. https://doi.org/10.1016/j.memsci.2013.03.019

[96] Oluwaseun, O. Burnett, D., Hann, R. and Haut, R. (2008) Application of Membrane Filtration Technologies to Drilling Wastes. Proceedings of Society of Petroleum Engineering Annual Technical Conference and Exhibition, Denver, CO, 21-24 September 2008, SPE-115587-MS.

[97] Zaidi, A., Simms, K. and Kok, S. (1992) The Use of Micro/Ultrafiltration for the Removal of Oil and Suspended Solids from Oilfield Brines. Water Science \& Technology, 25, 163-176. https://doi.org/10.2166/wst.1992.0245

[98] Mueller, J., Cen, Y. and Davis, R.H. (1997) Crossflow Microfiltration of Oily Water. Journal of Membrane Science, 129, 221-235. https://doi.org/10.1016/S0376-7388(96)00344-4

[99] He, Z., Lyu, Z., Gu, Q., Zhang, L. and Wang, J. (2019) Ceramic-Based Membranes for Water and Wastewater Treatment. Colloids and Surfaces A: Physicochemical and Engineering Aspects, 578, Article ID: 123513. https://doi.org/10.1016/j.colsurfa.2019.05.074

[100] Macedonio, F., Ali, A., Poerio, T., El-Sayed, E., Drioli, E. and Abdel-Jawad, M. (2014) Direct Contact Membrane Distillation for Treatment of Oilfield Produced Water. Separation and Purification Technology, 126, 69-81. https://doi.org/10.1016/j.seppur.2014.02.004

[101] Padaki, M., Murali, R.S., Abdullah, M.S., Misdan, N., Moslehyani, A., Kassim, M.A., Hilal, N. and Ismail, A.F. (2015) Membrane Technology Enhancement in Oil-Water Separation. A Review. Desalination, 357, 197-207.

https://doi.org/10.1016/j.desal.2014.11.023

[102] Weschenfelder, S.E., Mello, A.C.C., Borges, C.P. and Campos, J.C. (2015) Oilfield Produced Water Treatment by Ceramic Membranes: Preliminary Process Cost Estimation. Desalination, 360, 81-86. https://doi.org/10.1016/j.desal.2015.01.015

[103] Neto, G.L.O., Oliveira, N.G.N., Delgado, J.M.P.Q., Nascimento, L.P.C., Magalhaes, H.L.F., de Oliveira, P.L., Gomez, R.S., Neto, S.R.F. and Lima, A.G.B. (2021) Hydrodynamic and Performance Evaluation of a Porous Ceramic Membrane Module 
Used on the Water-Oil Separation Process: An Investigation by CFD. Membranes, 11, Article 121. https://doi.org/10.3390/membranes11020121

[104] Chen, M.L., Shang, R., Sberna, P.M., Luiten-Olieman, M.W.J., Rietveld, L.C. and Heijman, S.G.J. (2020) Highly Permeable Silicon Carbide-Alumina Ultrafiltration Membranes for Oil-in-Water Filtration Produced with Low-Pressure Chemical Vapor Deposition. Separation and Purification Technology, 253, Article ID: 117496. https://doi.org/10.1016/j.seppur.2020.117496

[105] Abbasi, M., Mirfendereski, M., Nikbakht, M., Golshenas, M. and Mohammadi, T. (2010) Performance Study of Mullite and Mullite-Alumina Ceramic MF Membranes for Oily Wastewaters Treatment. Desalination, 259, 169-178. https://doi.org/10.1016/j.desal.2010.04.013

[106] Hu, X., Yu, Y., Zhou, J., Wang, Y., Liang, J., Zhang, X., Chang, Q. and Song, L. (2015) The Improved Oil/Water Separation Performance of Graphene Oxide Modified $\mathrm{Al}_{2} \mathrm{O}_{3}$ Microfiltration Membrane. Journal of Membrane Science, 476, 200-204. https://doi.org/10.1016/j.memsci.2014.11.043

[107] Tan, L.L. (2010) Trends in Water Sector. Innovation, 12 p.

[108] Weschenfelder, S.E., Borges, C.P. and Campos, J.C. (2015) Oilfield Produced Water Treatment by Ceramic Membranes: Bench and Pilot Scale Evaluation. Journal of Membrane Science, 495, 242-251. https://doi.org/10.1016/j.memsci.2015.08.028

[109] Dong, S., Kim, E.-S., Alpatova, A., Noguchi, H., Liu, Y. and El-Din, M.-G. (2014) Treatment of Oil Sands Process-Affected Water by Submerged Ceramic Membrane Microfiltration System. Separation and Purification Technology, 138, 198-209. https://doi.org/10.1016/j.seppur.2014.10.017

[110] Beery, M., Pflieger, C. and Weyd, M. (2020) Sustainable Industrial Wastewater Reuse Using Ceramic Nanofiltration: Results from Two Pilot Projects in the Oil and Gas and the Ceramics Industries. Journal of Water Reuse and Desalination, 10, 462-474. https://doi.org/10.2166/wrd.2020.029

[111] Weschenfelder, S.E., Fonseca, M.J.C. and Borges, C.P. (2021) Treatment of Produced Water from Polymer Flooding in Oil Production by Ceramic Membranes. Journal of Petroleum Science and Engineering, 196, Article ID: 108021. https://doi.org/10.1016/j.petrol.2020.108021

[112] Piemonte, V., Mascis, L., Prisciandaro, M. and Di Paola, L. (2015) Reverse Osmosis Membranes for Treatment of Produced Water: A Process Analysis. Desalination and Water Treatment, 55, 565-574. https://doi.org/10.1080/19443994.2015.1014862

[113] Suwaileh, W., Pathak, N. Shon, H. and Hilal, N. (2020) Forward Osmosis Membranes and Processes: A Comprehensive Review of Research Trends and Future Outlook. Desalination, 485, Article ID: 114455.

https://doi.org/10.1016/j.desal.2020.114455

[114] Ogletree, L., Du, H. and Kommalapati, R. (2021) Shale Oil \& Gas Produced Water Treatment: Opportunities and Barriers for Forward Osmosis. In: Ince, M. and Ince, O.K., Eds., Osmotically Driven Membrane Processes, InTech Open, London.

[115] Nguyen, H.T., Nguyen, N.C., Chen, S.S., Ngo, H.H., Guo, W. and Li, C.W. (2015) A New Class of Draw Solutions for Minimizing Reverse Salt Flux to Improve forward Osmosis Desalination. Science of the Total Environment, 538, 129-136. https://doi.org/10.1016/j.scitotenv.2015.07.156

[116] Law, J.Y. and Mohammad, A.W. (2017) Multiple-Solute Salts as Draw Solution for Osmotic Concentration of Succinate Feed by Forward Osmosis. Journal of Industry and Engineering Chemistry, 51, 264-270. https://doi.org/10.1016/j.jiec.2017.03.011 
[117] McGinnis, R.L. and Elimelech, M. (2007) Energy Requirements of Ammonia-Carbon Dioxide forward Osmosis Desalination. Desalination, 207, 370-382. https://doi.org/10.1016/j.desal.2006.08.012

[118] Coday, B.D., Almaraz, N. and Cath, T.Y. (2015) Forward Osmosis Desalination of Oil and Gas Wastewater: Impacts of Membrane Selection and Operating Conditions on Process Performance. Journal of Membrane Science, 488, 40-55. https://doi.org/10.1016/j.memsci.2015.03.059

[119] Lee, K.P., Arnot, T.C. and Mattia, D. (2011) A Review of Reverse Osmosis Membrane Materials for Desalination-Development to Date and Future Potential. Journal of Membrane Science, 370, 1-22. https://doi.org/10.1016/j.memsci.2010.12.036

[120] Polasek, V., Talo, S. and Sharif, T. (2003) Conversion from Hollow Fiber to Spiral Technology in Large Seawater RO Systems-Process Design and Economics. Desalination, 156, 239-247. https://doi.org/10.1016/S0011-9164(03)00346-1

[121] Muraleedaaran, S., Li, X., Li, L. and Lee, R. (2009) Is Reverse Osmosis Effective for Produced Water Purification: Viability and ECONOMIC analysis. The SPE Western Regional Meeting, San Jose, CA, 24-26 March 2009, SPE-115952-MS. https://doi.org/10.2118/115952-MS

[122] Edalat, A. and Hoek, E. (2020) Techno-Economic Analysis of RO Desalination of Produced Water for Beneficial Reuse in California. Water, 12, Article 1850. https://doi.org/10.3390/w12071850

[123] Siriivedhin, T., McCue, J. and Dallbauman, L. (2004) Reclaiming Produced Water for Beneficial Use: Salt Removal by Electrodialysis. Journal of Membrane Science, 243, 335-343. https://doi.org/10.1016/j.memsci.2004.06.038

[124] Yan, H., Wang, Y., Wu, L., Shehzad, M.A., Jiang, C., Fu, R., Liu, Z. and Xu, T. (2019) Multistage-Batch Electrodialysis to Concentrate High-Salinity Solutions: Process Optimization, Water Transport, and Energy Consumption. Journal of Membrane Science, 570-571, 245-257. https://doi.org/10.1016/j.memsci.2018.10.008

[125] Tong, T. and Elimelech, M. (2016) The Global Rise of Zero Liquid Discharge for Wastewater Management: Drivers, Technologies, and Future Directions. Environmental Science \& Technology, 50, 6846-6855.

https://doi.org/10.1021/acs.est.6b01000

[126] Sosa-Fernandez, P.A., Post, J.W., Bruning, H., Leermakers, F.A.M. and Rijnaarts, H.H.M. (2018) Electrodialysis-Based Desalination and Reuse of Sea and Brackish Polymer-Flooding Produced Water. Desalination, 447, 120-132. https://doi.org/10.1016/j.desal.2018.09.012

[127] Sosa-Fernandez, P.A., Post, J.W., Ramdlan, M.S., Leermakers, F.A.M., Bruning, H. and Rijnaarts, H.M.M. (2020) Improving the Performance of Polymer-Flooding Produced Water Electrodialysis through the Application of Pulsed Electric Field. Desalination, 484, Article ID: 114424. https://doi.org/10.1016/j.desal.2020.114424

[128] Loganathan, K., Chelme-Ayala, P. and Gamal El-Din, M. (2015) Treatment of Basal Water Using a Hybrid Electrodialysis Reversal-Reverse Osmosis System Combined with a Low-Temperature Crystallizer for Near-Zero Liquid Discharge. Desalination, 36, 392-398. https://doi.org/10.1016/j.desal.2015.01.020

[129] Dallbauman, L. and Sirivedhin, T. (2005) Reclamation of Produced Water for Beneficial Use. Separation Science and Technology, 40, 185-200. https://doi.org/10.1081/SS-200041910

[130] Shaffer, D.L., Arias Chavez, L.H., Ben-Sasson, M., Romero-Vargas Castrillón, S., Yip, N.Y. and Elimelech, M. (2013) Desalination and Reuse of High-Salinity Shale 
Gas Produced Water: Drivers, Technologies, and Future Directions. Environmental Science \& Technology, 47, 9569-9583. https://doi.org/10.1021/es401966e

[131] Said, I.A., Chomiak, T.R., He, Z. and Li, Q. (2020) Low-Cost High-Efficiency Solar Membrane Distillation for Treatment of Oil Produced Waters. Separation and Purification Technology, 250, Article ID: 117170. https://doi.org/10.1016/j.seppur.2020.117170

[132] El-Bourawi, M.S., Ding, R.M.Z. and Khayet, M. (2006) A Framework for Better Understanding Membrane Distillation Separation Process. Journal of Membrane Science, 285, 4-29. https://doi.org/10.1016/j.memsci.2006.08.002

[133] Drioli, E., Ali, A. and Macedonio, F. (2015) Membrane Distillation: Recent Developments and Perspectives. Desalination, 356, 56-84. https://doi.org/10.1016/j.desal.2014.10.028

[134] Warsinger, D.M., Swaminathan, J., Guillen-Burrieza, E., Arafat, H.A., John, H. and Lienhard, V. (2015) Scaling and Fouling in Membrane Distillation for Desalination Applications: A Review. Desalination, 356, 294-313. https://doi.org/10.1016/j.desal.2014.06.031

[135] Alkhudhiri, A., Darwish, N. and Hilal, N. (2012) Membrane Distillation: A Comprehensive Review. Desalination, 287, 2-18.

https://doi.org/10.1016/j.desal.2011.08.027

[136] Hausmann, A., Sanciolo, P., Vasiljevic, T., Weeks, M. and Duke, M (2012) Integration of Membrane Distillation into Heat Paths of Industrial Processes. Chemical Engineering Journal, 211-212, 378-387. https://doi.org/10.1016/j.cej.2012.09.092

[137] Boo, C., Lee, J. and Elimelech, M. (2016) Omniphobic Polyvinylidene Fluoride (PVDF) Membrane for Desalination Shale Gas Produced Water by Membrane Distillation. Environmental Science \& Technology, 50, 12275-12282. https://doi.org/10.1021/acs.est.6b03882

[138] Chen, T.C. and Ho, C.D. (2010) Immediate Assisted Solar Direct Contact Membrane Distillation in Saline Water Desalination. Journal of Membrane Science, 358, 122-130. https://doi.org/10.1016/j.memsci.2010.04.037

[139] Dongare, P.D, Alabastri, A., Pedersen, S., Zodrow, K.R., Hogan, N.J., Neumann, O., Wu, J., Wang, T., Deshmukh, A., Elimelech, M., Li, Q., Nordlander, P. and Halas, N.J. (2017) Nanophotonics-Enabled Solar Membrane Distillation for Off-Grid Water Purification. Proceedings of the National Academy of Sciences of the United States of America, 114, 6936-6941. https://doi.org/10.1073/pnas.1701835114

[140] Wang, J.B., Tanuwidjaja, D., Bhattacharjee, S., Edalat, A., Jassby, D. and Hoek, E.M.V. (2020) Produced Water Desalination via Pervaporative Distillation. Water, 12, Article 3560. https://doi.org/10.3390/w12123560

[141] Lemjed, C.B., Haiji, M., Farhat, N., Tikri, F., Hamzaoui, A.H., Zorrig, W., Debez, A., Abdelly, C., Amjad, K. and Trabelski, I. (2021) One-Step Removal of Organic Matter and Heavy Metals from Tunisian Oil Field (TOF) Produced Water Using Soluble Sodium Silicate with a Unit Molar Ratio $\mathrm{SiO}_{2} / \mathrm{Na}_{2} \mathrm{O}$. Arabian Journal of Geosciences, 14, Article No. 591. https://doi.org/10.1007/s12517-021-06936-4

[142] Garcia-Segura, S., Eiband, M.M.S., de Melo, J.V. and Martínez-Huitle, C.A. (2017) Electrocoagulation and Advanced Electrocoagulation Processes: A General Review about the Fundamentals, Emerging Applications and Its Association with Other Technologies. Journal of Electroanalytical Chemistry, 801, 267-299. https://doi.org/10.1016/j.jelechem.2017.07.047

[143] Ma, H. and Wang, B. (2006) Electrochemical Pilot-Scale Plant for Oil Field Produced Wastewater by M/C/Fe Electrodes. Journal of Hazardous Materials, 138, 392-400. 
https://doi.org/10.1016/j.jhazmat.2005.09.043

[144] Madhavan, M.A. and Antony, S.P. (2021) Effect of Polarity Shift on the Performance of Electrocoagulation Process for the Treatment of Produced Water. Chemosphere, 263, Article ID: 128052.

https://doi.org/10.1016/j.chemosphere.2020.128052

[145] Ibrahim, A., Moussa, D.T., El-Naas, M.H. and Nasser, M.S. (2020) Perforated Electrode Design for Passivation Reduction during the Electrochemical Treatment of Produced Water. Journal of Water Process Engineering, 33, Article ID: 101091. https://doi.org/10.1016/j.jwpe.2019.101091

[146] Zheng, T. (2017) Treatment of Oilfield Produced Water with Electrocoagulation: Improving the Process Performance by Using Pulse Current. Journal of Water Reuse and Desalination, 7, 378-386. https://doi.org/10.2166/wrd.2016.113

[147] Gobbi, L.C., Nascimento, I.L., Muniz, E.P., Rocha, S.M. and Porto, P.S. (2018) Electrocoagulation with Polarity Switch for Fast Oil Removal from Oil in Water Emulsions. Journal of Environmental Management, 213, 119-125. https://doi.org/10.1016/j.jenvman.2018.01.069

[148] An, C., Huang, G., Yao, Y. and Zhao, S. (2017) Emerging Usage of Electrocoagulation Technology for Oil Removal from Wastewater: A Review. Science of the Total Environment, 579, 537-556. https://doi.org/10.1016/j.scitotenv.2016.11.062

[149] Fadali, O.A., Ebrahiem, E.E., El-Gamil, A. and Altaher, H. (2016) Investigation of the Electrocoagulation Treatment Technique for the Separation of Oil from Wastewater. Journal of Environmental Science and Technology, 9, 62-74. https://doi.org/10.3923/jest.2016.62.74

[150] Manilal, A.M., Soloman, P.A. and Basha, C.A. (2020) Removal of Oil and Grease from Produced Water Using Electrocoagulation. Journal of Hazardous, Toxic, and Radioactive Waste, 24, Article ID: 04019023. https://doi.org/10.1061/(ASCE)HZ.2153-5515.0000463

[151] Sardari, K., Fyfe, P., Lincicome, D. and Wickramasinghe, S.R. (2018) Aluminum Electrocoagulation Followed by Forward Osmosis for Treating Hydraulic Fracturing Produced Waters. Desalination, 428, 172-181. https://doi.org/10.1016/j.desal.2017.11.030

[152] Shamaei, L., Khorshidi, B., Perdicakis, B. and Sadrzadeh, M. (2018) Treatment of Oil Sands Produced Water Using Combined Electrocoagulation and Chemical Coagulation Technique. Science of the Total Environment, 645, 560-572. https://doi.org/10.1016/j.scitotenv.2018.06.387

[153] Rodriguez, A.Z., Wang, H., Hu, L., Zhang, Y. and Xu, P. (2020) Treatment of Produced Water in the Permian Basin for Hydraulic Fracturing: Comparison of Different Coagulation Processes and Innovative Filter Media. Water, 12, Article 770. https://doi.org/10.3390/w12030770

[154] Shokrollahzadeh, S., Golmohammad, F., Naseri, N., Shokouhi, H. and Arman-mehr, M. (2012) Chemical Oxidation for Removal of Hydrocarbons from Gas-Field Produced Water. Procedia Engineering, 42, 942-947.

https://doi.org/10.1016/j.proeng.2012.07.487

[155] Bessa, E., Sant'Anna Jr., G.L. and Dezotti, M. (2001) Photocatalytic/ $\mathrm{H}_{2} \mathrm{O}_{2}$ Treatment of Oil Produced Waters. Applied Catalysis B: Environmental, 29, 125-134. https://doi.org/10.1016/S0926-3373(00)00199-5

[156] Moraes, J.E.F., Silva, D.N., Quina, F.H., Chiavone-Filho, O. and Nascimento, C.A.O. (2004) Utilization of Solar Energy in the Photodegradation of Gasoline in Water and of Oil-Field-Produced Water. Environmental Science \& Technology, 38, 3746-3751. 
https://doi.org/10.1021/es034701i

[157] Scott, A.C., Zubot, W., MacKinnon, M.D., Smith, D.W. and Fedorak, P.M. (2008) Ozonation of Oil Sands Process Water Removes Naphthenic Acids and Toxicity. Chemosphere, 71, 156-160. https://doi.org/10.1016/j.chemosphere.2007.10.051

[158] Jiménez, S., Andreozzi, M., Micó, M.M., Álvarez, M.G. and Contreras, S. (2019) Produced Water Treatment by Advanced Oxidation Processes. Science of the Total Environment, 666, 12-21. https://doi.org/10.1016/j.scitotenv.2019.02.128

[159] Haneef, T., Mustafa, M.R.U., Wan Yusof, K., Hasnain Isa, M., Bashir, M.J.K., Ahmad, M. and Zafar, M. (2020c) Removal of Polycyclic Aromatic Hydrocarbons (PAHs) from Produced Water by Ferrate(VI) Oxidation. Water, 12, Article 3132. https://doi.org/10.3390/w12113132

[160] Camarillo, M.K. and Stringfellow, W.T. (2018) Biological Treatment of Oil and Gas Produced Water: A Review and Meta-Analysis. Clean Technologies and Environmental Policy, 20, 1127-1146. https://doi.org/10.1007/s10098-018-1564-9

[161] Lusinier, N., Seyssiecq, I., Sambusiti, C., Jacob, M., Lesage, N. and Roche, N. (2019) Biological Treatments of Oilfield Produced Water: A Comprehensive Review. SPE Journal, 24, 2135-2147. https://doi.org/10.2118/195677-PA

[162] Liu, G.-H., Ye, Z., Tong, K. and Zhang, Y.-H. (2013) Biotreatment of Heavy Oil Wastewater by Combined Upflow Anaerobic Sludge Blanket and Immobilized Biological Aerated Filter in a Pilot-Scale Test. Biochemical Engineering Journal, 72, 48-53. https://doi.org/10.1016/j.bej.2012.12.017

[163] Freire, D.D.C., Commarota, M.C. and Sant'Anna, G.L. (2001) Biological Treatment of Oilfield Produced Water in a Sequencing Batch Reactor. Environmental Technology, 22, 1125-1135. https://doi.org/10.1080/09593332208618203

[164] Tellez, G.T., Nirmalakhandan, N. and Gardea-Torresde, J.L. (2002) Performance Evaluation of an Activated Sludge System for Removing Petroleum Hydrocarbons from Oilfield Produced Water. Advances of Environmental Research, 6, 455-470. https://doi.org/10.1016/S1093-0191(01)00073-9

[165] Tellez, G.T., Nirmalakhandan, N. and Gardea-Torresdey, J.L. (2005) Kinetic Evaluation of a Field-Scale Activated Sludge System for Removing Petroleum Hydrocarbons from Oilfield-Produced Water. Environmental Progress, 24, 96-104. https://doi.org/10.1002/ep.10042

[166] Shokrollahzadeh, S., Azizmohseni, F., Golmohammad, F., Shokouhi, H. and Khademhaghighat, F. (2008) Biodegradation Potential and Bacterial Diversity of a Petrochemical Wastewater Treatment Plant in Iran. Bioresource Technology, 99, 61276133. https://doi.org/10.1016/j.biortech.2007.12.034

[167] Sharghi, E.A., Bonakdarpour, B. and Pakzadeh, M. (2014) Treatment of Hypersaline Produced Water Employing a Moderately Halophilic Bacterial Consortium in a Membrane Bioreactor: Effect of Salt Concentration on Organic Removal Performance, Mixed Liquor Characteristics and Membrane Fouling. Bioresource Technology, 164, 203-213. https://doi.org/10.1016/j.biortech.2014.04.099

[168] Gibson, D.T. and Subramanian, V. (1984) Microbial Degradation of Aromatic Hydrocarbons. In: Gibson, D.T., Ed., Microbial Degradation of Organic Compounds, Marcel Dekker, New York, 181-252.

[169] Smith, M.R. (1990) The Biodegradation of Aromatic Compounds by Bacteria. Biodegradation, 1, 191-206. https://doi.org/10.1007/BF00058836

[170] Van Agteren, M.H., Keuning, S. and Janssen, D.B. (1998) Handbook on Biodegradation of and Biological Treatment of Hazardous Organic Compounds. Kluwer Academic Publishers, Philadelphia. https://doi.org/10.1007/978-94-015-9062-4 
[171] El-Naas, M.H., Acio, J.A. and El Telib, A.E. (2014) Aerobic Biodegradation of BTEX: Progresses and Prospects. Journal of Environmental Chemical Engineering, 2, 11041122. https://doi.org/10.1016/j.jece.2014.04.009

[172] Farhadian, M., Duchez, D., Vachelard, C. and Larroche, C. (2008) Monoaromatics Removal from Polluted Water through Bioreactors-A Review. Water Research, 42, 1325-1341. https://doi.org/10.1016/j.watres.2007.10.021

[173] Fatone, F., DiFabio, S., Bolzonella, D. and Cecchi, F. (2011) Fate of Aromatic Hydrocarbons in Italian Municipal Wastewater Systems: An Overview of Wastewater Treatment Using Conventional Activated-Sludge Processes (CASP) and Membrane Bioreactors (MBRs). Water Research, 45, 93-104. https://doi.org/10.1016/j.watres.2010.08.011

[174] Kraume, M. and Drews, A. (2010) Membrane Bioreactors in Waste Water Treatment-Status and Trends. Chemical Engineering \& Technology, 33, 1251-1259. https://doi.org/10.1002/ceat.201000104

[175] Scholz, W. and Fuchs, W. (2000) Treatment of Oil Contaminated Wastewater in a Membrane Bioreactor. Water Research, 34, 3621-3629.

https://doi.org/10.1016/S0043-1354(00)00106-8

[176] Janson, A., Katebah, M., Santos, A., Minier-Matar, J.E., Hussian, A., Adham, S. and Judd, S.J. (2014) Assessing the Biotreatability of Produced Water from a Qatari Gas Field. SPE Journal, 20, Article ID: 173188. https://doi.org/10.2523/IPTC-17318-MS

[177] Fakhru'l-Razi, A., Pendashteh, A.R., Zurina, Z.A., Luqman Chuah, A., Dayang Radiah, A.B. and Madaeni, S.S. (2010) Application of Membrane-Coupled Sequencing Batch Reactor for Oilfield Produced Water Recycle and Beneficial Reuse. Bioresource Technology, 101, 6942-6949. https://doi.org/10.1016/j.biortech.2010.04.005

[178] Pendashteh, A.R., Fakhru'l-Razi, A., Maedani, S.S., Abdullah, L.C., Abidin, Z.Z. and Biak, D.R.A. (2011) Membrane Foulants Characterization in a Membrane Bioreactor (MBR) Treating Hypersaline Oily Wastewater. Chemical Engineering Journal, 168, 140-150. https://doi.org/10.1016/j.cej.2010.12.053

[179] Pendashteh, A.R., Abdullah, L.C., Fakhru'l-Razi, A., Madaeni, S.S., Abidin, Z.Z. and Biak, D.R.A. (2012) Evaluation of Membrane Bioreactor for Hypersaline Oily Wastewater Treatment. Process Safety and Environmental Protection, 90, 45-55. https://doi.org/10.1016/j.psep.2011.07.006

[180] Ebrahimi, M., Ashaghi, K.S., Engel, L., Willershausen, D., Mund, P., Bolduan, P. and Czermak, P. (2009) Characterization and Application of Different Ceramic Membranes for the Oil-Field Produced Water Treatment. Desalination, 245, 533-540. https://doi.org/10.1016/j.desal.2009.02.017

[181] Ebrahimi, M., Willershausen, D., Ashaghi, K.S., Engel, L., Placido, L., Mund, P., Bolduan, P. and Czermak, P. (2010) Investigations on the Use of Different Ceramic Membranes for Efficient Oil-Field Produced Water Treatment. Desalination, 250, 991-996. https://doi.org/10.1016/j.desal.2009.09.088

[182] Zhong, J., Sun, X. and Wang, C. (2003) Treatment of Oily Wastewater Produced from Refinery Processes Using Flocculation and Ceramic Membrane Filtration. Separation and Purification Technology, 32, 93-98. https://doi.org/10.1016/S1383-5866(03)00067-4

[183] Zhang, Z., Du, X., Carlson, K.H., Robbins, C.A. and Tong, T. (2019) Effective Treatment of Shale Oil and Gas Produced Water by Membrane Distillation Coupled with Precipitative Softening and Walnut Shell Filtration. Desalination, 454, 82-90. https://doi.org/10.1016/j.desal.2018.12.011

[184] Qiao, X., Zhang, Z., Yu, J. and Ye, X. (2008) Performance Characteristics of a Hy- 
brid Membrane Pilot-Scale Plant for Oilfield Produced Wastewater. Desalination, 225, 113-122. https://doi.org/10.1016/j.desal.2007.04.092

[185] Sheikhan, J.M., Zainab, I., Janson, A. and Adham, S. (2015) Qatargas Wastewater Treatment Plants: An Advanced Design for Water Reuse. International Petroleum Technology Conference, Doha, 6-9 December 2015, IPTC-18456-MS.

https://doi.org/10.2523/IPTC-18456-MS

[186] Adham, S., Hussain, A., Minier-Matar, J., Janson, A. and Sharma, R. (2018) Membrane Applications and Opportunities for Water Management in the Oil \& Gas Industry. Desalination, 440, 2-17. https://doi.org/10.1016/j.desal.2018.01.030

[187] Zhao, S.F., Hu, S.G., Zhang, X.F., Song, L., Wang, Y.L., Tan, M., Kong, L.X. and Zhang, Y. (2020) Integrated Membrane System without Adding Chemicals for Produced Water Desalination towards Zero Liquid Discharge. Desalination, 496, Article ID: 114693. https://doi.org/10.1016/j.desal.2020.114693

[188] Alfarhan, A.A. and Duane, M.J. (2011) Geochemistry and Modification of Oilfield Brines in Surface Pits in Northern Kuwait. Arabian Journal of Geosciences, 5, 1055-1068. https://doi.org/10.1007/s12517-011-0297-4

[189] Schlumberger (n.d.) Evaporation Pit Definition-Schlumberger Industry Glossary. https://www.glossary.oilfield.slb.com/en/Terms/e/evaporation_pit.aspx

[190] KEPA (Kuwait Environmental Public Authority) (2020) Environment Public Authority-Kuwait-Laws and Regulations 13 (Protection of Marine and Coastal Environment). https://epa.org.kw/en-us/ExecutiveLists

[191] AlAnezi, K., Al-Samhan, M., Belkharchouche, M., Abuhaimed, W., Alali, S., Alenizi, K. and Alfuraij, A. (2018) Comparative Analysis of Produced Water Collected from Different Oil Gathering Centers in Kuwait. Journal of Environmental Protection, 9, 736-750. https://doi.org/10.4236/jep.2018.96046

[192] Aleisa, E. and Al-Shayji, K. (2019) Analysis on Reclamation and Reuse of Wastewater in Kuwait. Kuwait Journal of Science \& Engineering, 7, 1-27.

[193] Oren, Y., Korngold, E., Daltrophe, N., Messalem, Y., Volkman, Y., Aronov, L., Weismann, M., Bouriakov, N., Glueckstern, P. and Gilron, J. (2010) Pilot Studies on High Recovery BWRO-EDR for Near Zero Liquid Discharge Approach. Desalination, 261, 321-330. https://doi.org/10.1016/j.desal.2010.06.010

[194] Nghiem, L.D., Elters, C., Simon, A., Tatsuya, T. and Price, W. (2015) Coal Seam Gas Produced Water Treatment by Ultrafiltration, Reverse Osmosis and Multi-Effect Distillation: A Pilot Study. Separation and Purification Technology, 146, 94-100. https://doi.org/10.1016/j.seppur.2015.03.022

[195] Koren, A. and Nadav, N. (1994) Mechanical Vapor Compression to Treat Oil Field Produced Water. Desalination, 98, 41-48. https://doi.org/10.1016/0011-9164(94)00130-8

[196] McGinnis, R.L., Hancock, N.T., Nowosielski-Slepowron, M.S. and McGurgan, G.D. (2013) Pilot Demonstration of the $\mathrm{NH}_{3} / \mathrm{CO}_{2}$ Forward Osmosis Desalination Process on High Salinity Brines. Desalination, 312, 67-74.

https://doi.org/10.1016/j.desal.2012.11.032

[197] Murodjon, S., Yu, X., Li, M., Duo, J. and Deng T. (2020) Lithium Recovery from Brines Including Seawater, Salt Lake Brine, Underground Water and Geothermal Water. In: Vizureanu, P., Ed., Thermodynamics and Energy Engineering, InTech Open, London. https://doi.org/10.5772/intechopen.90371

[198] Kumar, A., Fukuda, H., Hatton, T.A. and Lienhard, J.H. (2019) Lithium Recovery from Oil and Gas Produced Water: A Need for a Growing Energy Industry. ACS Energy Letters, 4, 1471-1474. https://doi.org/10.1021/acsenergylett.9b00779 
[199] Miller, H., Trivedi, P., Qiu, Y., Sedlacko, E.M., Higgins, C.P. and Borch, T. (2019) Food Crop Irrigation with Oilfield-Produced Water Suppresses Plant Immune Response. Environmental Science \& Technology Letters, 6, 656-661. https://doi.org/10.1021/acs.estlett.9b00539

[200] Dolan, F.C., Cath, T.Y. and Hogue, T.S. (2018) Assessing the Feasibility of Using Produced Water for Irrigation in Colorado. Science of the Total Environment, 640-641, 619-628. https://doi.org/10.1016/j.scitotenv.2018.05.200

[201] Echchelh, A., Hess, T. and Sakrabani, R. (2018) Reusing Oil and Gas Produced Water for Irrigation of Food Crops in Drylands. Agricultural Water Management, 206, 124-134. https://doi.org/10.1016/j.agwat.2018.05.006

[202] Shaikh, S.S., Abu-Dieyeh, M.H., Al Naemi, F.A., Ahmed, T. and AlGhouti, M.A. (2020) Environmental Impact of Utilization of "Produced Water" from Oil and Gas Operations in Turfgrass Systems. Scientific Reports, 10, Article ID: 15051. https://doi.org/10.1038/s41598-020-72069-5

[203] Sedlacko, D.M., Jahn, C.E., Heuberger, A.L., Sindt, N.M., Miller, H.M., Borch, T., Blaine, A.C., Cath, T.Y. and Higgins, C.P. (2019) Potential for Beneficial Reuse of Oil and Gas-Derived Produced Water in Agriculture: Physiological and Morphological Responses in Spring Wheat (Triticum aestivum). Environmental Toxicology and Chemistry, 38, 1756-1769. https://doi.org/10.1002/etc.4449

[204] Pica, N.E., Carlson, K., Steiner, J.J. and Waskom, R. (2017) Produced Water Reuse for Irrigation of Non-Food Biofuel Crops: Effects on Switchgrass and Rapeseed Germination, Physiology and Biomass Yield. Industrial Crops and Products, 100, 65-76. https://doi.org/10.1016/j.indcrop.2017.02.011

[205] Burkhardt, A., Gawde, A., Cantrell, C.L., Baxter, H.L., Joyce, B.L., Stewart, C.N. and Zheljazkov, V.D. (2015) Effects of Produced Water on Soil Characteristics: Plant Biomass, and Secondary Metabolites. Journal of Environmental Quality, 44, 1938-1947. https://doi.org/10.2134/jeq2015.06.0299

[206] Seldacko, D.M., Chaparro, J.M., Heuberger, A.L., Cath, T.Y. and Higgins, C.P. (2020) Effect of Produced Water Treatment Technologies on Irrigation-Induced Metal and Salt Accumulation in Wheat (Triticum aestivum) and Sunflower (Helianthus annuus). Science of the Total Environment, 740, Article ID: 140003. https://doi.org/10.1016/j.scitotenv.2020.140003

[207] Hirayama, A., Maegaito, M., Kawaguchi, M., Ishikawa, A., Sueyoshi, M., Al-Bemani, A.S., Mushtaque, A., Esechie, H., Al-Mazrui, S.A., Al-Haddabi, M.H. and Al-Khanjari, S.S. (2002) Omani Oil Fields Produced Water: Treatment and Utilization. The SPE International Petroleum Conference and Exhibition in Mexico, Villahermosa, 10-12 February 2002, SPE-74413-MS. https://doi.org/10.2118/74413-MS

[208] Ibrahim, Y., Marroff, A. and Wafi, M. (2009) Effect of Irrigation with Gas Produced Water Enriched with $\mathrm{CO}_{2}$ on Alfalfa Growth, Quality and Mineral Content. Iranian Journal of Science and Technology Transaction B: Engineering, 10, 36-46.

[209] Atia, F.A.M., Al-Ghoutia, M.A., Al-Naimi, F., Abu-Dieyeh, M., Ahmed, T. and Al-Meer, S.H. (2019) Removal of Toxic Pollutants from Produced Water by Phytoremediation: Applications and Mechanistic Study. Journal of Water Process Engineering, 32, Article ID: 100990. https://doi.org/10.1016/j.jwpe.2019.100990

[210] Clay, L. and Pichtel, J. (2019) Treatment of Simulated Oil and Gas Produced Water via Pilot-Scale Rhizofiltration and Constructed Wetlands. International Journal of Environmental Research, 13, 185-198. https://doi.org/10.1007/s41742-018-0165-0

[211] Murray-Gulde, C., Heatley, J.E., Karanfil, T., Rodgers Jr., J.H. and Myers, J.E. (2003) Performance of a Hybrid Reverse Osmosis-Constructed Wetland Treatment System 
for Brackish Oil Field Produced Water. Water Research, 37, 705-713. https://doi.org/10.1016/S0043-1354(02)00353-6

[212] Ji, G.D., Sun, T.H., Zhou, Q.X., Sui, X., Chang, S.J. and Li, P.J. (2002) Constructed Subsurface Flow Wetland for Treating Heavy Oil-Produced Water of the Liaohe Oilfield in China. Ecological Engineering, 18, 459-465.

https://doi.org/10.1016/S0925-8574(01)00106-9

[213] Stefanakis, A.I., Prigent, S. and Breuer, R. (2018) Integrated Produced Water Management in a Desert Oilfield Using Wetland Technology and Innovative Reuse Practices. In: Stefanakis, A., Ed., Constructed Wetlands for Industrial Wastewater Treatment, John Wiley \& Sons, Hoboken, 25-42.

https://doi.org/10.1002/9781119268376.ch1

[214] Breuer, R. and Grissemann, E. (2011) Produced Water Treatment Using WetlandsReducing the Environmental Impact of Oilfield Operations. SPE European Health, Safety and Environmental Conference in Oil and Gas Exploration and Production, Vienna, 22-24 February 2011, SPE-140124-MS. https://doi.org/10.2118/140124-MS

[215] Rambeau, O., Morales de Lafond, R. Baldoni, P., Gosselin, J.P. and Baccou, J.C. (2004) Low Salt Petroleum Produced Water Reuse: A Farming Alternative outside the Food Chain. Water Science \& Technology, 50, 139-147.

https://doi.org/10.2166/wst.2004.0109

[216] Lahlou, F.Z., Mackey, H.R., McKay, G., Onwusogh, U. and Al-Ansari, T. (2020) Water Planning Framework for Alfalfa Fields Using Treated Wastewater Fertigation in Qatar: An Energy-Water-Food Nexus Approach. Computers \& Chemical Engineering, 141, Article ID: 106999.

https://doi.org/10.1016/j.compchemeng.2020.106999

[217] Ahmad, A.Y. and Al-Ghouti, M.A. (2020) Approaches to Achieve Sustainable Use and Management of Groundwater Resources in Qatar: A Review. Groundwater for Sustainable Development, 11, Article ID: 100367. https://doi.org/10.1016/j.gsd.2020.100367

[218] Zubari, W. (2017) An Overview of the GCC Unified Water Strategy, 2016-2035. 12 th Arabian Gulf Water Conference, Bahrain, 28-30 March 2017, 10 p.

[219] Paleologos, E.K., Al Nahyan, M.T. and Farouk, S. (2018) Risks and Threats of Desalination in the Arabian Gulf. IOP Conference Series: Earth Environmental Science, 191, Article ID: 012008.

https://iopscience.iop.org/article/10.1088/1755-1315/191/1/012008

https://doi.org/10.1088/1755-1315/191/1/012008

[220] Hoepner, T. and Lattemann, S. (2002) Chemical Impacts from Seawater Desalination Plants-A Case Study of the Northern Red Sea. Desalination, 152, 133-140. https://doi.org/10.1016/S0011-9164(02)01056-1 